\title{
Role of Mitochondrial Protein Import in Age-Related Neurodegenerative and Cardiovascular Diseases
}

\author{
Andrey Bogorodskiy ${ }^{1}$, Ivan Okhrimenko ${ }^{1,+}+\mathbb{D}$, Dmitrii Burkatovskii ${ }^{1,+}\left(\mathbb{D}\right.$, Philipp Jakobs ${ }^{2}$, Ivan Maslov ${ }^{1}$, \\ Valentin Gordeliy ${ }^{1,3,4,5}$, Norbert A. Dencher ${ }^{1,6}$, Thomas Gensch ${ }^{7}{ }^{10}$, Wolfgang Voos ${ }^{8}$, Joachim Altschmied ${ }^{2,9}$, \\ Judith Haendeler ${ }^{2}\left(\mathbb{D}\right.$ and Valentin Borshchevskiy ${ }^{1,3,4, *}$
}

1 Research Center for Molecular Mechanisms of Aging and Age-Related Diseases, Moscow Institute of Physics and Technology, 141701 Dolgoprudny, Russia; andrey.bogorodskiy@phystech.edu (A.B.);

ivan.okhrimenko@phystech.edu (I.O.); burkatovskiy.ds@phystech.edu (D.B.);

ivan.v.maslov@phystech.edu (I.M.); g.valentin@fz-juelich.de (V.G.);

norbert.dencher@physbiochem.tu-darmstadt.de (N.A.D.)

2 Environmentally-Induced Cardiovascular Degeneration, Central Institute of Clinical Chemistry and Laboratory Medicine, Medical Faculty, University Hospital and Heinrich-Heine-University Düsseldorf, 40225 Düsseldorf, Germany; philipp.jakobs@hhu.de (P.J.); joalt001@uni-duesseldorf.de (J.A.); juhae001@hhu.de (J.H.)

3 Institute of Biological Information Processing (IBI-7: Structural Biochemistry), Forschungszentrum Jülich, 52428 Jülich, Germany

4 JuStruct: Jülich Center for Structural Biology, Forschungszentrum Jülich, 52428 Jülich, Germany

5 Institut de Biologie Structurale (IBS), Université Grenoble Alpes, CEA, CNRS, 38400 Grenoble, France

6 Physical Biochemistry, Chemistry Department, Technical University of Darmstadt,

check for

updates

Citation: Bogorodskiy, A.; Okhrimenko, I.; Burkatovskii, D.; Jakobs, P.; Maslov, I.; Gordeliy, V.; Dencher, N.A.; Gensch, T.; Voos, W.; Altschmied, J.; et al. Role of Mitochondrial Protein Import in Age-Related Neurodegenerative and Cardiovascular Diseases. Cells 2021, 10, 3528. https://doi.org/10.3390/ cells10123528

Academic Editor: Ted M. Dawson

Received: 15 November 2021

Accepted: 12 December 2021

Published: 14 December 2021

Publisher's Note: MDPI stays neutral with regard to jurisdictional claims in published maps and institutional affiliations.

Copyright: (c) 2021 by the authors. Licensee MDPI, Basel, Switzerland. This article is an open access article distributed under the terms and conditions of the Creative Commons Attribution (CC BY) license (https:/ / creativecommons.org/licenses/by/ $4.0 /)$. 64289 Darmstadt, Germany

7 Institute of Biological Information Processing (IBI-1: Molecular and Cellular Physiology), Forschungszentrum Jülich, 52428 Jülich, Germany; t.gensch@fz-juelich.de

8 Institute of Biochemistry and Molecular Biology (IBMB), Faculty of Medicine, University of Bonn, 53113 Bonn, Germany; wolfgang.voos@uni-bonn.de

9 IUF—Leibniz Research Institute for Environmental Medicine, 40225 Düsseldorf, Germany

* Correspondence: v.borshchevskiy@fz-juelich.de

+ These authors contributed equally to this work.

Abstract: Mitochondria play a critical role in providing energy, maintaining cellular metabolism, and regulating cell survival and death. To carry out these crucial functions, mitochondria employ more than 1500 proteins, distributed between two membranes and two aqueous compartments. An extensive network of dedicated proteins is engaged in importing and sorting these nuclear-encoded proteins into their designated mitochondrial compartments. Defects in this fundamental system are related to a variety of pathologies, particularly engaging the most energy-demanding tissues. In this review, we summarize the state-of-the-art knowledge about the mitochondrial protein import machinery and describe the known interrelation of its failure with age-related neurodegenerative and cardiovascular diseases.

Keywords: mitochondria; mitochondrial protein import; age-related diseases; Alzheimer's disease; Parkinson's disease; cardiovascular disease; TERT; cardiolipin

\section{Introduction}

In general, mitochondria are known as the powerhouses of cells since their major function is to produce ATP as an energy source. Besides that, mitochondria are required for the regulation of calcium homeostasis, lipid and amino acid metabolism, and biosynthesis of heme and iron-sulfur complexes. Over the last years, it has become evident that mitochondria are signaling organelles, which regulate processes like apoptotic cell death as well as nuclear transcription [1].

Mitochondrial functions decline with the aging process of the organism, as mitochondria are subjected to a variety of biochemical stress conditions. Those lead to the 
accumulation of damaged molecules that directly or indirectly interfere with the regular biochemical processes occurring in mitochondria. Most prominent in this context are oxidative stress reactions caused by the accumulation of reactive oxygen species (ROS). ROS are generated as byproducts during the metabolic reactions of the OXPHOS process, in addition to detrimental environmental impacts [2]. Mitochondrial biogenesis capacity declines at older age, in particular due to the accumulation of mutations in the mitochondrial and nuclear genome. These mutations lead to the generation of defective or aberrant enzymatic components of the mitochondrial structure and metabolism, resulting in mitochondrial and eventually cellular dysfunction. This general problem is exacerbated by a relatively error-prone mitochondrial genome replication and inefficient repair processes [3].

As cellular survival depends on the maintenance of protein function, also called proteostasis, an efficient protein biogenesis process is a prerequisite to providing the required proteins for all cellular functions. Due to the dual genetic origin of mitochondrial proteins, a portion is encoded in the mitochondria, but most are nuclear-encoded; efficient protein biosynthesis and subsequent import into the organelle are essential for mitochondrial function. In addition to the transport processes into the organelle, mitochondrial polypeptides-irrespective of their source-need to undergo proper folding and assembly into active enzymes or enzyme complexes. Thus, the biogenesis of mitochondrial proteins represents a very complex process that is also prone to errors and defects correlating with diseases. Of note, not only the proteins in the inner (IMM) and outer mitochondrial membranes (OMM) are required for proper complex assembly, but also the phospholipid composition of the mitochondrial membranes plays a critical role. For example, it has been demonstrated that the lipid composition changes with age; in particular, the content of the mitochondria-specific lipid cardiolipin declines, which may play a central role in age-related diseases [4]. Age-related accumulation of cholesterol in mitochondria is a proposed trigger of Alzheimer's disease (AD) [5,6].

Stress- or age-related damage of individual proteins or even the full organelle is counteracted by an array of different protective processes. On the protein side, a variety of chaperone and protease enzymes help to refold or remove damaged polypeptides before they accumulate and induce malfunction. To deal with unfolded polypeptides, mitochondria contain the full set of Hsp70- and Hsp60-type chaperones, similar to their bacterial ancestors [7]. In addition, each mitochondrial subcompartment, including the membranes, contains protease enzymes that specifically digest polypeptides that could not be refolded or assembled into their respective enzyme complexes [8]. Failure of this protein quality control (PQC) system contributes to many human diseases [9]. Specific signaling processes from mitochondria to the nucleus, summarized under the expression "unfolded protein response (mtUPR)", increase the mitochondrial PQC capacity by enhancing the expression of the respective chaperones and proteases. If these protective processes fail, defective mitochondria themselves seem to be removed by a regulated and specific form of autophagy, named mitophagy [10].

As mitochondrial functions and quality control are largely dependent on the import of proteins produced in the cytoplasm, disruptions in import create cascading effects in mitochondria leading to diminished metabolic function, increased production of ROS, and failures in regulated cell death response [11]. Mitochondrial dysfunction is increased particularly with older age. For several diseases, most importantly affecting organs that particularly depend on mitochondria, namely the brain and the heart, mitochondrial dysfunction has been broadly described [1,12-15].

Not surprisingly, a number of recent reviews describe different aspects of mitochondrial function and structure, in particular mitochondrial machineries for protein import and assembly [16]. Considerably fewer reviews can be found on the connection between mitochondrial protein import and aging-related diseases [17].

This review provides an up-to-date overview of mitochondria translocation and sorting machinery and highlights the connection between its malfunction and diseases. We discuss the role of defective mitochondrial protein import in the two most common 
neurodegenerative diseases (Parkinson's and Alzheimer's diseases) and cardiovascular diseases (CVD), focusing on cardiolipin and the unique protective role of mitochondrial telomerase reverse transcriptase (TERT).

\section{Mitochondrial Protein Import Machinery}

Nuclear-encoded mitochondrial proteins typically contain signaling sequences that are recognized in the cytosol by the mitochondrial protein import machinery and transported into mitochondria in an ATP-dependent manner (for review, see [16]). Mitochondrial targeting sequences can either be $N$-terminal (e.g., subunit 8 of cytochrome c oxidase), internal (e.g., ADP / ATP carrier), or C-terminal (e.g., VDAC) [18-21]). N-terminal presequences are the most frequent and can be recognized by mitochondria import machinery either during or after translation [22]. After import, around 70\% of presequences are cleaved by mitochondrial processing peptidases (MPP) [23]. Internal and C-terminal mitochondrial targeting sequences can only be recognized after protein translation is complete. Mitochondrial proteins employing internal or C-terminal targeting sequences are frequently hydrophobic and require assistance from chaperones such as Hsp70/90 to prevent misfolding and aggregation in the cytoplasm.

Mitochondrial protein recognition occurs at the translocase of the outer membrane (TOM) complex. The TOM component TOMM20 acts as a direct receptor for $N$-terminal signal sequences, while TOMM70 seems to be dedicated to the recognition of hydrophobic proteins with internal signal sequences. These hydrophobic proteins reach the mitochondrial surface, often bound by cytosolic chaperones that also can interact with TOMM70 [16]. After passing through pore formed by the TOM complex, proteins are sorted between TIM22, TIM23, SAM, or MIA machinery, depending on the protein destination and fold (Figure 1). Insertase OXA1L inserts mitochondria encoded proteins into IMM. In yeast, mitochondrial insertase Oxa1p additionally assists in inserting multi $\alpha$-helical nuclearencoded proteins, but the same behavior for human OXA1L was not yet verified [24,25].

In addition to signaling sequences, mitochondrial protein import efficiency is further enhanced by localization of mRNA encoding mitochondrial proteins near the OMM and its translation in the vicinity of the translocation machinery [26-28], thus bypassing the need for intermediate chaperone-mediated transport. The observed mRNA localization near OMM is guided either by the interaction of protein nascent chains with TOM complex or by the interaction between $3^{\prime}$ mRNA end, specific RNA-binding proteins (RBPs), and OMM proteins. In human cells, RBPs are only incompletely described, but some proteins were found to co-localize with mRNA on the OMM surface, e.g., CluH and PUM [29,30]. Recent advances in proximity labeling identified several new RBPs [31] on the OMM surface, including SYNJ2BP, which persists on the OMM surface after disruption of protein synthesis and binds several mRNAs of OXPHOS proteins. RBPs' participation in mitochondrial protein transport presents another potential avenue of protein import disruption caused by mutations/aging/environmental factors. 


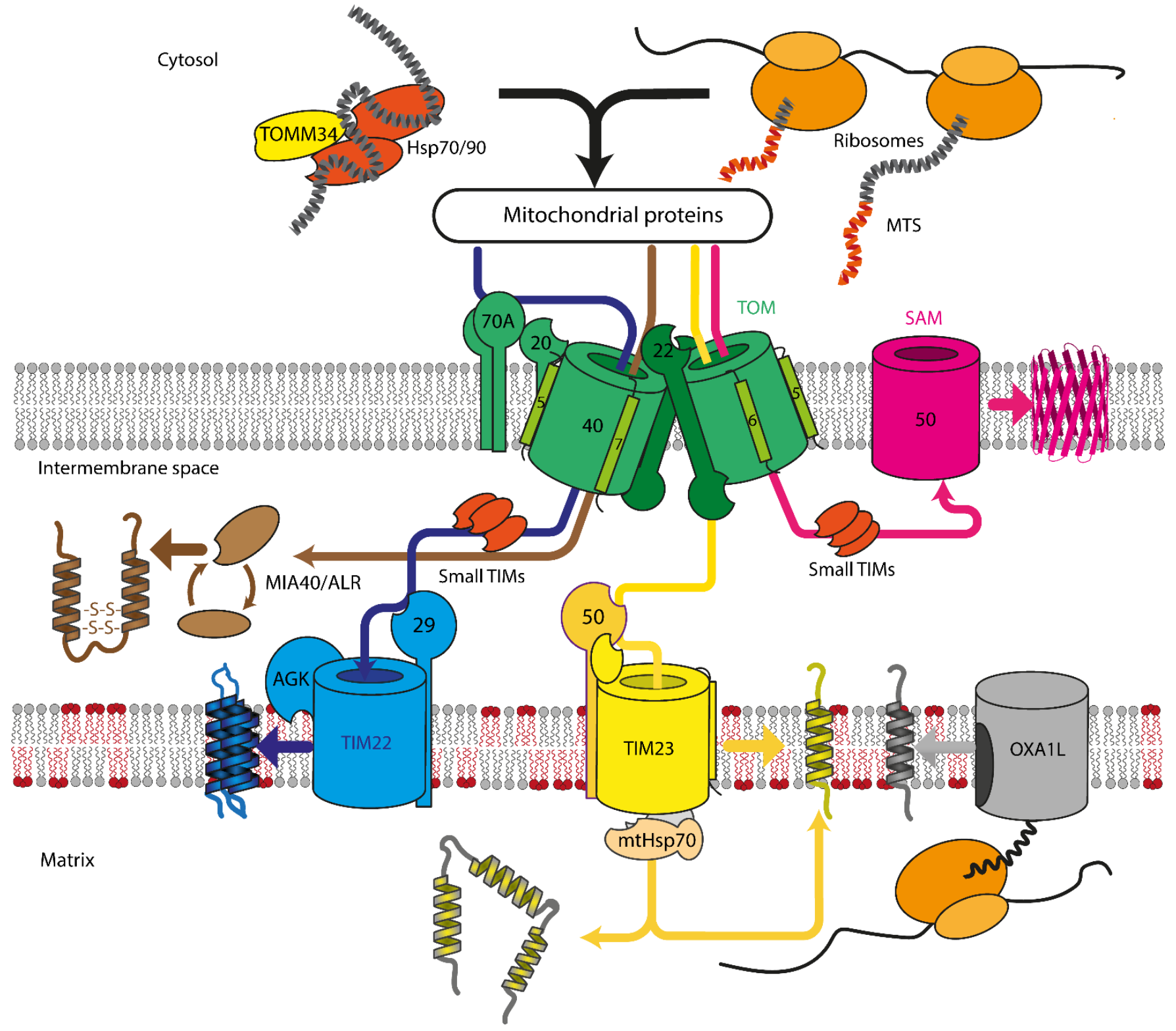

Figure 1. Overview of mitochondrial protein import in mammalian cells. Proteins are recognized by TOMM70A/ TOMM20/TOMM22 and are imported either co- or post-translationally through the TOM complex, containing TOMM40, TOMM22, TOMM5, TOMM6, and TOMM7. Hydrophobic proteins employ Hsp70/90 complex with participation of TOMM34 to prevent misfolding in the cytoplasm. Inside the intermembrane space, depending on the nature and destination of the precursor protein, proteins are delivered to different compartments. $\beta$-barrels of the outer membrane are inserted into the outer mitochondrial membrane by SAM complex. Intermembrane space proteins with cysteine motifs are oxidized to the mature form by the MIA40/ALR system. Metabolite carriers are inserted into IMM by TIM22 complex, composed of TIMM22, TIMM29, and acylglycerol kinase (AGK). Other IMM and matrix proteins are inserted/transported by TIM23 complex. Primary TIMM23 pore is associated with TIMM50 (recognizes signals and interacts with TOM complex), TIMM44 with associated $\mathrm{mtHsp} 70$ (forming presequence-associated motor helping matrix protein transfer), or TIMM21 for protein release into IMM. Mitochondrial-encoded proteins are inserted into the IMM by OXA1L insertase from the matrix side.

\subsection{Translocase of Outer Mitochondrial Membrane}

The TOM complex is the main entry gate for the mitochondrial proteins, consisting of the proteins TOMM40, TOMM22, TOMM20, TOMM70A, TOMM5, TOMM6, and TOMM7. TOMM40 forms the main transmembrane pore of the TOM complex, while the rest of TOMM proteins help in signal recognition, complex stabilization, and assembly. 
Both dimeric and trimeric structures of the human TOM complex were observed using CryoEM and chemical cross-linking [32,33]. In dimeric form, twin tilted $\beta$-barrels of TOMM40 are flanked by twin TOMM22 proteins, and each TOMM40 is surrounded by singular TOMM5,6,7 proteins, which help with complex stabilization [32,34] (Figure 1). TOMM22, TOMM6, and TOMM40 have exposed negatively charged surface patches which serve as recognition sites for positively charged signaling sequences of mitochondrial proteins. TOM complex may also form trimers, which are likely required for lateral release of protein into the OMM [33], but otherwise, trimer formation is relatively poorly understood.

TOMM70A, weakly attached to the TOM complex, recognizes hydrophobic cytosolic proteins with internal mitochondrial targeting sequences. Transport of such proteins in the cytosol is frequently assisted by the Hsp70/Hsp90 chaperone complex and, possibly, by co-chaperone TOMM34. [35,36]. TOMM20, also weakly associated with TOM complex, is a receptor for mitochondrial protein precursors with $N$-terminal targeting signals. TOMM20 additionally assists TOMM70A during protein translocation [35].

After being imported through the TOM complex, proteins are sorted by downstream complexes. Sorting and assembly machinery (SAM) complex inserts $\beta$-barrels such as porins into OMM. Mitochondrial intermembrane space assembly (MIA) assists in the maturation of IMS proteins with cysteine motifs. Translocase of inner mitochondrial membrane (TIM) 22 and 23 complexes transfer protein to IMM and matrix, with TIM22 used exclusively for IMM metabolite carrier proteins, while TIM23 transports the rest of the proteins. More details of these processes are given in the following sections of this chapter.

\subsection{Sorting and Assembly Machinery Component}

The SAM complex governs the assembly of $\beta$-barrel proteins (such as porins, TOMM40, and SAMM50 itself) of the outer membrane after their precursors were translocated through the TOM complex. In yeast and, likely, in humans, $\beta$-barrel proteins pass through TOM complex employing internal or $C$-terminal $\beta$-hairpin as a signaling sequence [21]. After emerging from the TOM complex, small Tim chaperones bind to the precursor proteins to prevent their aggregation; then, proteins are passed to the SAM complex that embeds $\beta$-barrel into the OMM from the IMS side. Partner proteins of SAMM50 are not well defined in humans [37]. Evidence exists that metaxins partner with SAMM50, e.g., metaxin-1 forms a complex with SAMM50 [38-40]. However, only a small portion of metaxin-1 is associated with SAMM50, and a large portion exists in a separate complex with metaxin-2 [40].

\subsection{Mitochondrial Intermembrane Space Assembly}

The import of small IMS proteins with multiple cysteine residues occurs via the mitochondrial intermembrane space assembly (MIA), which captures imported proteins in the IMS via the thiol-disulfide exchange. MIA substrates possess characteristic cysteine motifs $\mathrm{CX}_{3} \mathrm{C}$ and $\mathrm{CX}{ }_{9} \mathrm{C}$ (where $\mathrm{X}$ are amino acids), which are oxidized to form mature forms of proteins in the IMS. MIA consists of two proteins: Mia40 (alternatively named CHCHD4Coiled-Coil-Helix-Coiled-Coil-Helix Domain Containing 4) and ALR (augmenter of liver regeneration). MIA substrates are kept in reduced form during translocation through the outer membrane and are oxidized by Mia40 in IMS. Mia40 is then reoxidized by the ALR protein, which in turn is interacting with cytochrome c [41]. Similar to the substrates import, Mia40 requires its own entrapment by oxidation of twin $\mathrm{CX}_{9} \mathrm{X}$ motifs. Oxidationdriven import of the IMS-targeted proteins is much slower than the import of presequence targeted proteins and is strongly dependent on the availability of MIA40 [42]. After oxidation, mature proteins of the IMS are released.

\subsection{Translocase of Inner Mitochondrial Membrane}

The inner mitochondrial membrane contains two distinct translocation complexes: TIM22 and TIM23. TIM22 is used for the import of some IMM proteins containing internal signaling sequences, while TIM23 is used for the remaining IMM proteins and all the 
matrix proteins. TIM23 is much more abundant and possesses the ability to change the mode of transport depending on the attached subunits.

\subsubsection{TIM23}

The translocase of the inner mitochondrial membrane 23 (TIM23) complex sorts proteins to the matrix or IMM. The main components of the TIM23 complex are the proteins TIMM23 (main pore), TIMM50, TIMM17, and TIMM44 [43]. TIMM17 has two variants, TIMM17A and TIMM17B, with the latter being more abundant [44]. TIMM50 recognizes presequence-containing proteins on the TOM complex IMS side and passes them into the TIM23 complex [45]. TIMM44 regulates the attachment of mtHsp70 (mortalin) to the TIM23 complex from the matrix side. mtHsp70 binds to the precursor proteins and uses ATP hydrolysis to pull them inside. mtHsp70 co-chaperones such as MAGMAS, MCJ, and DNAJC19 also interact with TIM23 complex and modulate the ATPase activity of mtHsp70 on the matrix side of the IMM [45]. Together, TIMM44, mtHsp70, MAGMAS, and DNAJC19 form a presequence-associated motor (PAM), which facilitates ATP-dependent protein import into the matrix. Inside the matrix, MPP remove presequences, and the mature form of imported protein is released. Single $\alpha$-helical proteins are released from TIM23 directly into the IMM with the help of TIMM21 and ROMO1, with TIMM21 substituting PAM assembly in that case.

\subsubsection{TIM22}

TIM22 complex inserts into IMM hydrophobic $\alpha$-helical proteins containing multiple internal targeting sequences, which include metabolite carriers and subunits TIMM17, TIMM23, and TIMM22 of translocases [46]. TIMM22 protein is laterally exposed into the membrane cavity and, together with TIMM29 and AGK, forms the TIM22 complex [47-49]. TIMM29 interacts with the TOM complex, further facilitating the transfer of proteins from the cytosol into IMM [50]. Hydrophobic $\alpha$-helical proteins are likely delivered by hexamer complexes of TIMM9/TIMM10a and TIMM9/10a/10b, which were found directly attached to the TIM22 complex [48].

\subsection{Mitochondrial Lipids}

Essentially, the complete translocation and sorting machinery consist of membranebound or transmembrane complexes. Their assembly and functioning are influenced by the lipid composition of the mitochondrial membranes. Many mitochondrial lipids originate from the endoplasmic reticulum and Golgi complex, but some of the crucial lipids are synthesized directly in mitochondria [51,52]. In eukaryotes, cardiolipin is exclusively synthesized in the mitochondria, where it remains throughout the life of the cell.

Studies in yeast revealed that cardiolipin influences the import of proteins not only via the TIM complexes (for review, see [53]) but also via the TOM complexes [54]. Besides its regulatory function on complex assembly of the electron transport chain (ETC) [52] as well as its unique role as a proton trap at the membrane surface participating in oxidative phosphorylation and therefore in ATP synthesis [55], cardiolipin also mediates interactions between Tim 23 and Tim50 in yeast [56]. Cardiolipin was also found between TOMM22 and TOMM40 in the CryoEM structure of the human TOM complex, but the role of this arrangement is yet to be determined [33]. Mitochondrial membranes also contain low amounts of cholesterol and are sensitive to changes in cholesterol level [57,58], which is, in turn, finely regulated by the mitochondrial protein import machinery [59].

\section{Neurodegenerative Diseases}

Neurodegenerative diseases (ND) encompass conditions of cognitive impairment accompanied by changes in the behavior and functioning of the organism. Common for $\mathrm{ND}$ is the progressive death of nerve cells (neurodegeneration) in many cases related to mitochondria malfunction [60]. There is a bulk of evidence that malfunction of the mitochondrial protein import system causes ND or is associated with them. In this chapter, 
we review the evidence of the interrelation of mitochondrial protein import machinery with Parkinson's and Alzheimer's diseases.

\subsection{Parkinson's Disease}

Parkinson's disease (PD) is an ND that mostly affects the elderly population, with a prevalence of $2-3 \%$ for people above 65 years. PD patients suffer from bradykinesia, rigidity, rest tremor, sleeping and mood disorders, cognitive impairment, autonomic dysfunction, as well as sensory symptoms and pain (reviewed in [61]). The loss of dopaminergic (DA) neurons in the substantia nigra and the accumulation of $\alpha$-synuclein (ASYN) are considered the main hallmarks of PD. It is likely that DA neurons suffer most from PD because of their high bioenergetic demands and axonal arborization [62]. This confirms that the mitochondria, being the cell powerhouses, play a key role in PD pathogenesis.

PD can be initially caused by monogenic mutations (see review [63]), as well as harmful environmental factors and aging. Among the genes in which mutations have been identified that cause early-onset PD, PINK1 and PRKN have been directly linked to mitochondria. They encode a mitochondrial protein, the PTEN induced kinase 1 (PINK1), and a cytosolic E3 ubiquitin ligase (PARKIN/PRKN), that is recruited to mitochondria under pathological circumstances. In healthy cells, these proteins act together as a sensor for mitochondrial quality and contribute to the maintenance of mitochondrial function [10] (Figure 2A). The $\mathrm{N}$-terminal mitochondrial targeting sequence in PINK1 is partially transported through TOM and TIM23 complexes and cleaved by mitochondrial peptidases (MPP, PARL, m-AAA, and ClpXP) in the matrix [64]. The truncated PINK1 detaches from the mitochondrial membranes and gets degraded in the cytosol [65]. In stressed mitochondria with disturbed membrane potential, PINK1 cannot pass through TIM23. Instead, it accumulates at the OMM in the full-length form and forms a high molecular weight PINK1 complex (HMW PINK1 complex) that contains TOM complex proteins and a PINK1 dimer [66]. Although the mechanistic details and the exact role of the PINK1 complex on potential-deficient mitochondria is still not entirely clarified, it is well established that the accumulated full-length PINK1 recruits the cytosolic PARKIN to the mitochondrial surface. The process involves PINK1 phosphorylation and ubiquitin phosphorylation, which in turn activates PARKIN ligase activity [67]. Activated PARKIN ubiquitinates substrates on the OMM, which are afterward phosphorylated by PINK1. This attracts signaling proteins and induces autophagosome formation, thus eliminating the dysfunctional mitochondria [68] (Figure 2B).

The detailed composition of this HMW PINK1 complex is still not identified and is of interest in the context of mitochondrial transport. At least three TOM complex proteins (TOMM20, TOMM22, and TOMM40) have been commonly identified as HMW PINK1 complex components [69]. Additionally, TOMM7 was shown to be essential for the stabilization of PINK1 on OMM of stressed mitochondria [70]. The exact position of PINK1 in the complex is a matter of debate. Crosslinking experiments suggest that the accumulated PINK1 is associated with TOMM20 but not with TOMM40 in depolarized mitochondria [71]. Therefore, it is reasonable to expect that PINK1 is laterally released into the OMM. The number of TOMM40 components within an HMW PINK1 complex is also not determined yet. Recent cryo-EM structures of dimeric and trimeric human TOM complexes suggest that only trimeric TOMM40 can open laterally into the OMM and thus release PINK1 [33].

Taken together, the PINK1/PARKIN-dependent signaling pathway seems to play an important role in the removal of damaged mitochondria under stress conditions. However, most experiments analyzing PINK1 function used a treatment with uncoupling chemicals like CCCP, resulting in a complete loss of the inner membrane potential in all mitochondria within a cell-a situation that certainly does not reflect the situation in living organisms. Hence, it remains to be established what role the PINK1/PARKIN-induced mitophagy plays in the emergence of the Parkinson pathology in human patients. 

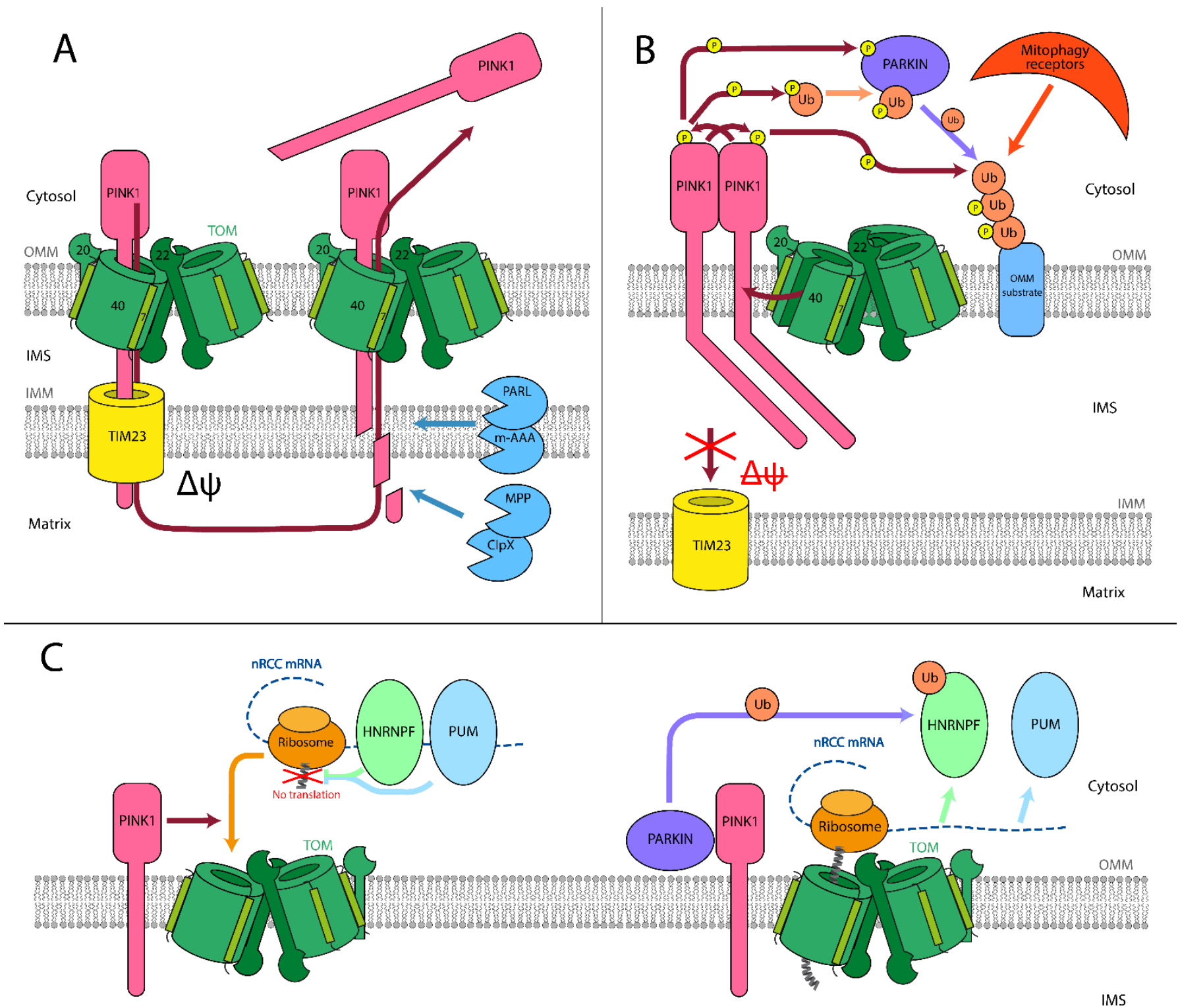

Figure 2. Role of mitochondrial protein import in Parkinson's disease. (A) PINK1/PARKIN mitochondrial quality control model. In healthy mitochondria, PINK1 is transported through both TOM and TIM complexes, utilizing the IMM electrostatic potential. Afterward, it is cleaved inside the matrix and on the IMM by mitochondrial proteases. The remaining part of PINK1 is dislocated into the cytosol, where it is degraded. This process allows keeping PINK1 levels on the OMM negligible. (B) In unhealthy mitochondria, PINK1 is unable to be transported through the TIM complex. It is ejected from TOMM40 laterally into the OMM, and the ejection is facilitated by TOMM7. PINK1 remains in connection with TOMM20. In that state, it accumulates on the OMM and starts forming homodimers within an HMW PINK1 complex. In dimeric form, PINK1 phosphorylates its dimeric partner and starts to phosphorylate PARKIN and ubiquitin. Phosphorylated PARKIN and ubiquitin form complex and ubiquitinate targets on the OMM. PINK1 phosphorylates ubiquitin on such targets, which attracts mitophagy receptors, starting the mitophagy process. (C) Proposed $n R C C$ translation regulation mechanism. While the $n R C C m R N A$ is in the cytosol and away from the mitochondria, PUM and HNRNPF are attached to it and serve as translation repressors. PINK1 attracts mRCC mRNA to the TOM complex on the outer mitochondrial membrane. Then, PARKIN removes the translation repressors HNRNPF and PUM from the mRNA. For HNRNPF protein, this process involves ubiquitination by PARKIN. When the repressors are released, co-translational synthesis through the TOM complex starts.

Emerging evidence suggests that PINK1 and PARKIN may participate in the mitochondrial translation of nuclear-encoded respiratory chain complexes (nRCC) (Figure 2C) near the mitochondrial surface. While the $n R C C m R N A$ is not located near the mitochondria, 
translation of $n R C C m R N A$ is repressed by proteins PUMILIO (PUM) and HNRNPF. PINK1 accumulates on the OMM of mitochondria with impaired IMM potential, binds to TOM complex, attracts $n R C C$ mRNA to the OMM, and facilitates association of the nascent chain with the TOM complex. PARKIN acts downstream of PINK1, ubiquitinating HNRNPF, thus displacing it from the $n R C C m R N A$. PINK1 and PARKIN are also associated with the displacement of other $n R C C$ mRNA translation repressors: PUM, GW182, DCP1, and POP2 [72]. Interestingly, the described mechanism relies on PINK1 being integrated into the mitochondrial membrane, which, as mentioned before, is the first step of mitophagy. Therefore, $n R C C$ synthesis activation may serve as the first immediate step for rescuing the damaged mitochondria.

Mutations in PINK1/PARKIN have been established as risk factors in hereditary forms of PD (see [63,73] for review). For some of these mutations, their mechanism of action has been studied. PINK1 mutations have been shown to affect its stability (I368N [74], L347P [75]), recruitment to mitochondria (S402A [66]), autophosphorylation (G309D, L347P [75], G411S [76]), ubiquitin phosphorylation (G411S [76]), and dimerization (Q456X [76]). Meanwhile, PARKIN mutations are known to cause its aggregation (C289G, C418R [77]) and loss of E3 activity (M434K, C441R [78]). All of these mutations interfere with the PINK1/PARKIN MQC and/or $n R C C$ mRNA regulation system and presumably result in PD.

In addition to the more indirect involvement of the import system in the PINK1/PARKIN signaling pathway, an additional-more direct-pathological event has been proposed to take place during PD. Accumulation of mutant forms of $\alpha$-synuclein (ASYN), another genetic factor in PD, as aggregated proteins in so-called Lewy bodies is considered a major hallmark of PD pathology. Some experiments directly link ASYN-based pathological pathways to defects in mitochondrial protein import. The expression of certain pathological forms of ASYN has been revealed to impair mitochondrial import of proteins [79]. However, the mechanism of this impairment remains elusive. TOMM40 levels have been shown to decrease in cells overexpressing ASYN [80], although the exact mechanism is not defined, as this decrease might be caused indirectly by mitochondrial damage. There is an experimentally supported theory that oligomeric, dopamine-modified, or S129E mutant ASYN might bind to the mitochondrial protein import receptor TOMM20, preventing its association with TOMM22, which would lead to a decrease in import through the TOM complex [79]. The transport of ASYN itself into the mitochondria is also debated. An earlier report proposed that ASYN is imported through the TOM machinery [81], although more recent data advocate against that, as no interaction with TOMM40 was detected [79]. Recent experiments point at a potential interaction of ASYN with the voltage-dependent anion channel (VDAC), a major pore protein in the OMM, suggesting that ASYN might be transported into mitochondria through it [82,83]. However, although the normally cytosolic ASYN may affect the pore properties of VDAC, a direct transport through the pore has not been demonstrated convincingly yet.

\subsection{Alzheimer's Disease}

Alzheimer's disease (AD) is the most common age-related form of ND (60-80\% of all known dementia). AD occurs in only $3 \%$ of cases at the age of 70 , but in more than $30 \%$ of cases at the age of 90 [84]. Despite the tremendous progress in science and medicine, the causes and mechanisms associated with this pathology remain unclear more than 100 years after the disease was first described [85].

Various mechanisms have been proposed for the involvement of $A \beta$ peptides in AD. For a long time, the focus of research and treatment of Alzheimer's disease has been on extracellular plaques consisting of A $\beta$ peptides. According to the "amyloid hypothesis", aggregates of amyloid fibrils that settle outside the neurons in dense formations (senile or neuritic plaques) are the causative agent of $\mathrm{AD}$ [86]. It is hypothesized that the intracellular $\mathrm{A} \beta$ peptides in human neurons are involved in $\mathrm{AD}$ before the formation of extracellular plaques [87-89]. 
As it is well established that mitochondria function declines with age, numerous attempts were made to elucidate a connection between mitochondrial dysfunction and AD [90]. Recently the hypothesis of the "mitochondrial cascade" emerged [91], which proposed a causative role of impaired mitochondrial function as a factor in the etiology of AD. The "mitochondrial cascade hypothesis" suggests mitochondria as a trigger and target for $\mathrm{A} \beta$-mediated intracellular dysfunction and damage in the early stages of AD. The exposure to monomeric and oligomeric $A \beta$ peptides $(A \beta)$ negatively affects mitochondrial function, causing an increase in free radical (particularly ROS) stress and damage to the mitochondrial genome, thereby disrupting the normal functioning of neurons [92-94].

Additionally, A $\beta$ directly and indirectly affects the mitochondrial protein import during AD. The clogging of TIM/TOM [95-97] or mitochondrial preprotein aggregation [98] lowers the import of mitochondrial proteins coded in the nucleus, particularly the subunits of the complexes of the oxidative phosphorylation machinery, which, in turn, affects the mitochondrial membrane potential (MMP, $\Delta \psi$ ) [99]. Lowering the $\Delta \psi$ impairs protein import into mitochondria driven by electric field [100] and lowers the amount of ATP produced by mitochondria [101,102], but ATP, particularly, is needed for TIM to force the import protein polypeptide chain movement [103]. The positive feedback lets tiny deviations in protein import caused by prolonged $A \beta$ action escalate and become important for the whole organism [104]. This is directly related to the importance of mitochondria function and constant high-intensity metabolism, which they drive [105-107].

Amyloid beta precursor protein (APP) is localized in mitochondria-associated membranes (MAM; a special part of the endoplasmatic reticulum) [108]. The sequential proteolysis of APP by membrane secretase enzymes produces an A $\beta$ peptide. APP fragment of amino acid residues number from 672 to 713 corresponds to $A \beta_{1-42}$ peptide and $672-711$ to $A \beta_{1-40}$ [99]. $A \beta$ peptides are continuously produced throughout life in a healthy brain, and an increase in either total $A \beta$ levels or $A \beta_{1-42} / A \beta_{1-40}$ ratio is associated with a late onset of AD pathogenesis [109]. Some experiments showed a noticeable portion of APP in OMM [96,110,111]. Additionally, it was reported that APP is degraded in MAM and OMM by mitochondrial $\gamma$-secretase [112], producing the $C$-terminal fragment (CTF or C99 [109]) on the cytoplasmic side and probably A $\beta[96,108,111]$. Based on these few experiments, it was proposed that APP blocks TIM/TOM complex arresting translocation [95-97] (Figure 3C).

A $\beta$ peptide indirectly affects the initial steps of the mitochondrial preprotein transfer through TIM/TOM complex by the formation of $A \beta$-preprotein cytosolic coaggregates outside mitochondria [98]. Importantly, $A \beta_{1-42}$ induced 10 times greater effect than $A \beta_{1-40}$. This correlates with the properties of $A \beta_{1-42}$, which is more hydrophobic and has a greater tendency to form aggregates and amyloidogenic fibrils than $A \beta_{1-40}$. However, $A \beta_{1-42}$ and $A \beta_{1-40}$ peptides did not affect the structure of preprotein translocase complexes and interacted only weakly with mitochondria without the influence on the inner membrane potential [98] (Figure 3A). These findings obtained for human cells are supported by similar data for $S$. cerevisiae and $C$. elegans. In the latter case, cytosolic aggregation of mitochondrial preproteins was observed, which are known to be downregulated in AD, and the aggregation of ASYN and A $\beta$ was enhanced because of mitochondrial protein import dysfunction [113].

Relatively high (but sub-lethal) concentrations of oligomerized A $\beta$ species inhibited the import of mtGFP with $N$-terminal mitochondrial targeting sequence (MTS) [21]. Notably, high concentrations of $\mathrm{A} \beta$ led to the decrease of the MMP, increase in ROS concentration, and altered mitochondrial morphology only after a long period of treatment, after the decline of import of two endogenous nuclear-encoded mitochondrial proteins, mortalin/mtHsp70 and Tom20 [114].

It was reported that $A \beta_{1-40}$ and $A \beta_{1-42}$ are imported in vitro into the mitochondria through the TOM complex by the same mechanism as mitochondria-targeted proteins (Figure 3B). Positively charged amino acid residues of A $\beta$, localized closely at the $N$ terminal cation binding domain [115], are possibly sufficient for recognition by the TOM 
complex. As the import was insensitive to valinomycin, it was concluded that $\Delta \psi$ is not necessary for the A $\beta$ import, unlike other matrix proteins [116]. Unfortunately, no timecourse experiments were performed, and conclusions are only based on co-sedimentation of $\mathrm{A} \beta$ and mitochondria [116,117].

Mitochondrial presequence peptidase (PreP) is responsible for degrading presequences and other short unstructured peptides just after translocation through TIM/TOM complex. PreP is also able to degrade $A \beta_{1-42}$ and $A \beta_{1-40}$ [118]. Furthermore, it was claimed that in $S$. cerevisiae and rat mitochondrial matrix, $\mathrm{A} \beta$ inhibits PreP degradation of presequences and nuclear-encoded mitochondrial proteins [119]. This, presumably, results in the accumulation of non-folded mitochondrial preproteins and processing intermediates, leading to the decrease of mitochondrial function [120] (Figure 3D). In a mouse model, the cognitive functions were partially restored by PreP overexpression [121]. However, this correlation does not directly connect PreP with the A $\beta$ degradation in the mitochondrial matrix. Even more, this observation of $A \beta$ inhibition of preprotein processing inside intact human mitochondria was experimentally excluded recently $[90,98]$.

Mortalin, the mitochondrial chaperon Hsp70, is an essential part of the TIM23 complex [122,123]. The inhibition of mortalin induced mitochondrial fragmentation and increased $A \beta$-mediated cytotoxicity as well as mitochondrial dysfunction. Moreover, overexpression of mortalin suppressed $A \beta$-mediated mitochondrial fragmentation and cell death [124] (Figure 3E). These facts led to the conclusion that decreased functionality of mortalin influences protein import, particularly in AD (but also in PD and Huntington's disease) [17]. It should be noted that as far as mortalin is involved in numerous processes in the cytoplasm and mitochondria [125], then the alteration of mortalin expression or functionality could exacerbate a systematic severe effect and influence on mitochondrial protein import could be indirect, especially because a relatively small portion of total cell mortalin is involved in TIM23 machinery.

The cholesterol amount in mitochondrial membranes is dependent on the activity of mitochondrial protein import complexes [59]. Mitochondrial membranes contain relatively low amounts of cholesterol, but these changes are important $[57,58]$. Cholesterol affects the $A \beta$ maturation, directly influencing the activity of $\gamma$-secretase in MAM during proteolytic degradation of amyloid precursor protein (APP) [126-128]. Cholesterol also interacts with the membrane part of APP [129,130], affects the activity of $\beta$-secretase [131,132] and $\alpha$-secretase [133], defining the sequential cleavage of APP either via the amyloidogenic or non-amyloidogenic pathway, respectively. The C99 fragment of APP is the precursor of $\mathrm{A} \beta$ peptides, also involved in Alzheimer's disease. It regulates cellular cholesterol trafficking [134].

A high, non-physiological concentration of $A \beta$ is often used in experiments to produce notable measurable effects. However, high concentration of any peptide could produce a severe effect on mitochondria, so the relation of obtained results to the mitochondrial protein import mechanisms in disease and healthy state is still not settled. The experimentally obtained decline of import of mitochondria targeted GFP of approximately $20 \%$ by treatment of predominantly aggregated $\mathrm{A} \beta_{1-42}$ at $10 \mu \mathrm{M}$ concentration for $96 \mathrm{~h}$ [114] seems to be an illustration of this statement. Similar experiments with monomeric $A \beta_{1-40}$ and $A \beta_{1-42}$ at a concentration of $3.5 \mu \mathrm{M}$ showed the formation of co-aggregates with mitochondrial-targeted proteins [98]. Therefore, the aggregation state of $A \beta$ should always be taken into account during basic research because monomers, small oligomers, and fibrils of $A \beta$ could produce different effects. We assume that a mixture of monomeric, oligomeric, and fibrillar species was applied in widely cited experiments in which the import of $A \beta$ through TOM was studied [116]. Close to physiological concentration (100 nM) of A $\beta$ was used, but without any pretreatment and no examination of the presence and amount of the oligomeric state of $A \beta$. At the same time, therapeutic approaches already exist, which target fibrils or monomers of $A \beta$ [135], and even small oligomers [136,137]. 


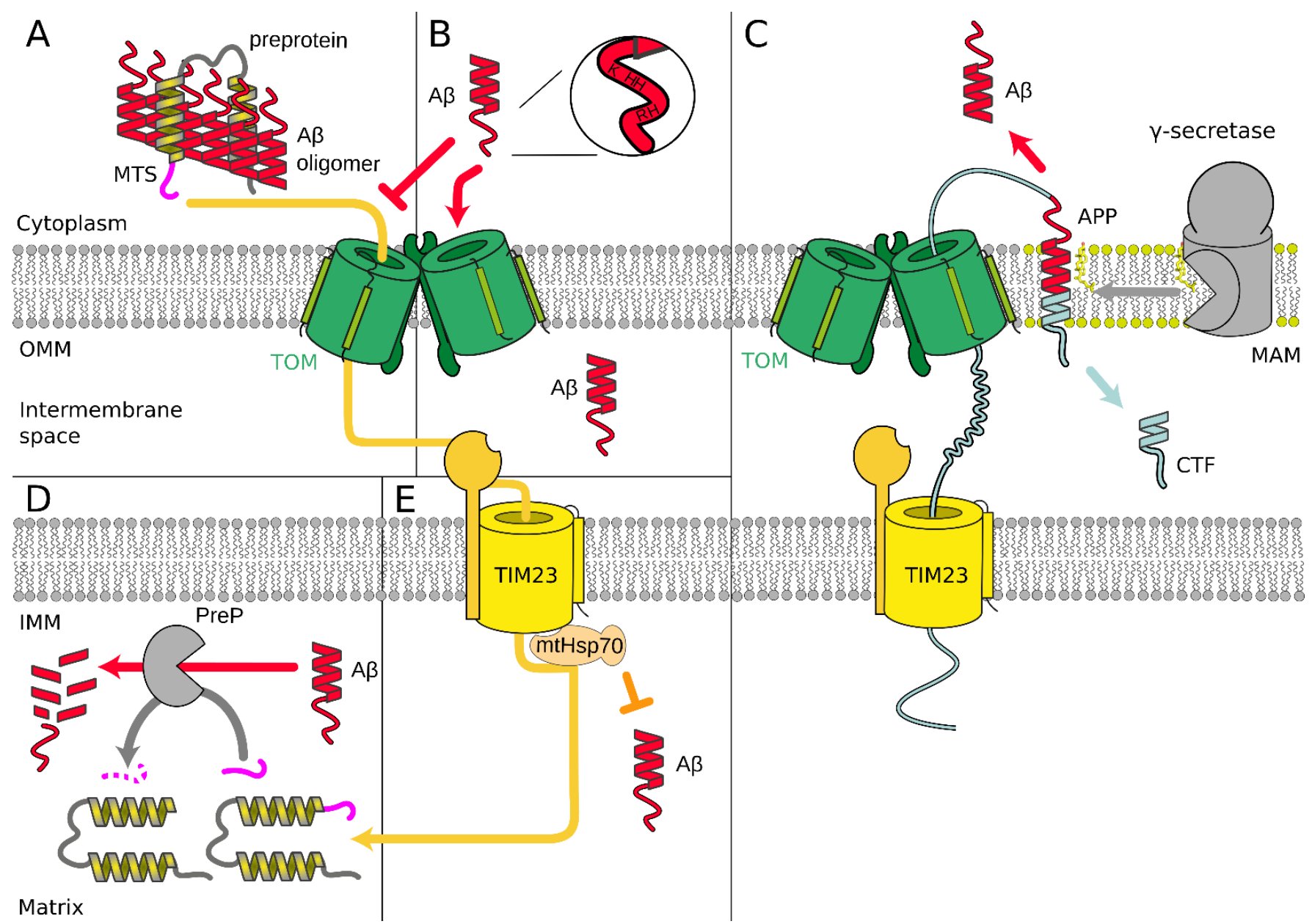

Figure 3. (A) $A \beta$ peptides form cytosolic $A \beta$-preprotein coaggregates that inhibit the initial steps of the mitochondrial preprotein transfer through TIM/TOM complex [98]. (B) Positively charged amino acid residues of A $\beta$, localized closely at the $N$-terminal cation binding domain [115], are possibly sufficient for recognition by the TOM complex. A $\beta$ species possibly could be imported into the mitochondria through the TOM complex by the same mechanism as proteins with the signal peptide of mitochondrial localization [116]. (C) Amyloid beta precursor protein (APP) in mitochondria-associated membranes (MAM) [108] is degraded by mitochondrial $\gamma$-secretase [112], producing A $\beta[96,108,111]$. APP possibly blocks TIM/TOM complex by arresting translocation [95-97]. (D) Mitochondrial presequence peptidase (PreP) is able to degrade $\mathrm{A} \beta$ [118]. A $\beta$ possibly inhibits PreP function of degrading presequences and processing protein intermediates after translocation through TIM/TOM complex [119]. (E) Overexpression of mortalin (mtHsp70) suppresses A $\beta$-mediated mitochondrial fragmentation and cell death [124].

\section{Cardiovascular Diseases}

Cardiovascular diseases (CVD) are the leading cause of death in the world. There are many factors known to increase the risk for CVD. The major modifiable risk factors include, e.g., unhealthy diet, physical inactivity, mental stress, and obesity. Despite the ongoing search for pharmaceuticals and improving healthcare, the risk of developing CVD is consistently high in developed countries. In Europe, more than 4 million people die every year from CVD. In 2016, cardiovascular complications, such as hypertension, atherosclerosis, pathological hypertrophy, ischemic heart disease, and myocardial infarction, resulted in economic costs in Europe amounting to a total of EUR 210 billion [138]. Thus, treatment of these complications has a tremendous impact. Therefore, an overall understanding of the underlying causes and mechanisms is required to find new treatments and improve those already established. It is indisputable that many cells of the cardiovascular systemincluding cardiomyocytes, smooth muscle cells, fibroblasts, and endothelial cells-rely on proper mitochondrial functionality. Moreover, accumulating evidence reveals novel 
links between mitochondrial dysfunction and CVD pathogenesis. Over the last years, mitochondrial dynamics, mitochondrial networks, and mitochondrial biogenesis have become of particular interest besides improper functioning of the respiratory chain and mitochondrial reactive oxygen species as potential new therapeutic routes in CVD. However, the mitochondrial protein import machinery has been greatly overlooked in most of the studies with respect to the cardiovascular system, although proteins have to be imported into the mitochondria for the proper functionality of these organelles [139]. Nevertheless, phenotyping of mice within the frame of the International Mouse Phenotyping Consortium [140] clearly demonstrates that the mitochondrial protein import machinery has an essential vital function, as the homozygous inactivation of numerous genes coding for constituents of the TOM/TIM complexes results in embryonic lethality. Over the last years, it has become clear that the phospholipid composition of the OMM and IMM plays a pivotal role in the assembly and function of the mitochondrial protein import machinery.

\subsection{Cardiolipin}

The signature phospholipid of the mitochondrial membranes is cardiolipin, as alluded to above in detail (Section 2.5). Several studies in ischemia and reperfusion injury in the heart demonstrated that the cardiolipin content is reduced by up to $25 \%$ resulting in reduced ETC assembly and activity $[141,142]$. Since the unsaturated fatty acids within cardiolipin consist of approximately $90 \%$ of linoleic acid [142], it was hypothesized that the dietary intake of linoleic acid would improve the outcome in heart failure patients. Indeed, experimental studies in mice revealed that linoleic acid supplementation increased the content of cardiolipin in the heart of mice and improved fractional shortening. However, the dysregulated respirasome assembly, which occurred in heart failure, could not be repaired by increased intake of linoleic acid and, thus, enhanced cardiolipin content [143]. Therefore, further studies are needed to understand which other factors are required besides the cardiolipin content in protecting the heart. Of note, cardiolipin consists of numerous unsaturated fatty acids; thus, it is tempting to speculate that the increase in reactive oxygen species in ischemia and reperfusion injury in the heart leads to oxidation of cardiolipin [144] and, thus, to dysregulated assembly not only of the ETC complexes but also of the protein import machinery.

\subsection{Mitochondrial Telomerase Reverse Transcriptase}

Recently a protein known to be imported into the mitochondria via the TOM and TIM machinery containing an $N$-terminal mitochondrial import sequence has been demonstrated to be protective in ischemia and reperfusion injury-Telomerase Reverse Transcriptase (TERT).

Telomerase has been described as being essential to counteract telomere erosion in rapidly dividing cells, such as germ cells and stem cells. However, later on, it was revealed that its catalytic subunit TERT also plays a crucial role in tissues with low proliferative capacity, such as the heart and the vasculature. In that context, it was shown that physical exercise upregulates TERT expression in the myocardium, where telomere length was not affected [145], and in the thoracic aorta [146]. Moreover, it was demonstrated that TERT is expressed in different cell types of the heart, namely in cardiomyocytes as well as in endothelial and mesenchymal cells and that it is upregulated after cardiac injury [147].

Notably, TERT is not only present in cell nuclei but also in mitochondria, which is easily explained by the presence of a bona fide mitochondrial targeting sequence at the $\mathrm{N}$ terminus of the protein [148] in addition to the nuclear localization signal in its C-terminus. It has been demonstrated that TERT is imported into the mitochondria via the TOMM and TIMM machinery in the cardiovascular system (Figure 4) [149]. Mitochondrial TERT has protective functions, which are exerted by-among others-reduction of mitochondrial reactive oxygen species and protection of mitochondrial DNA [149-152]. 


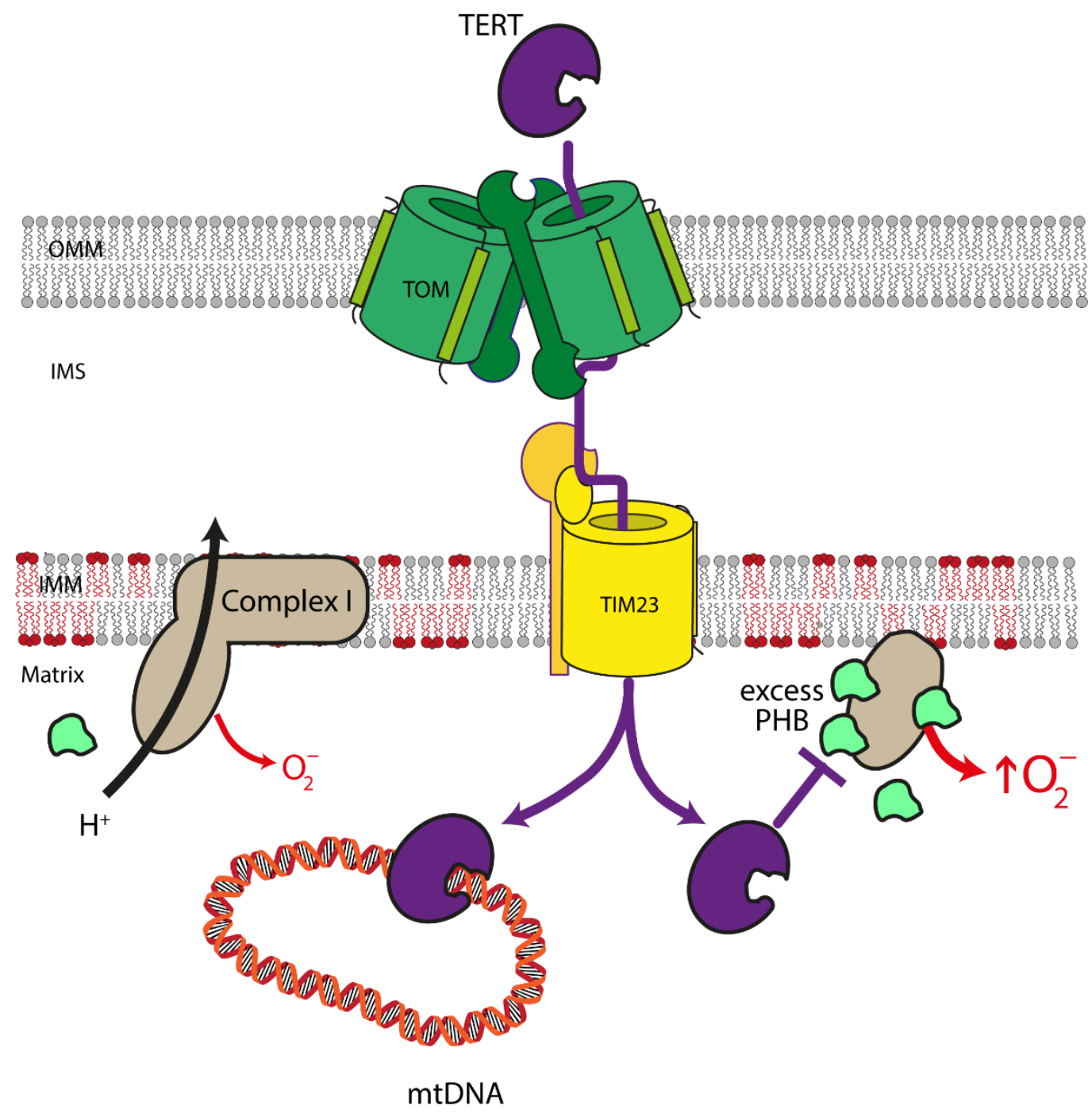

Figure 4. Mitochondrial functions of TERT in the cardiovascular system. In the mitochondria, Telomerase Reverse Transcriptase (TERT) binds to mitochondrial DNA (mtDNA) and protects it against damage. In addition, mitochondrial TERT improves the stoichiometry of the different subunits of complex I of the electron transport chain. Moreover, an increase in mitochondrial TERT reduces the levels of Prohibitin (PHB) in these organelles, which—when in excess—stabilizes free matrix arm subunits of complex I of the electron transport chain resulting in increased production of mitochondrial superoxide. Consequently, mitochondrial TERT improves complex I composition and activity, decreases mitochondrial reactive oxygen levels, and, thereby, contributes to enhanced mitochondrial functionality.

Early experiments aimed at elucidating the functions of TERT in the cardiovascular system demonstrated that overexpression of TERT inhibits cardiomyocyte apoptosis ex vivo and in vivo [153] and enhances the regenerative properties of endothelial progenitor cells [154]. However, it was not clear whether nuclear or mitochondrial TERT accounts for these effects. With respect to mitochondrial functions, it was later shown that TERTdeficiency results in reduced electron transport chain activity in the heart and an increase in lesions in mitochondrial DNA $[149,155]$, strongly supporting a mitochondrial function of TERT in this organ. Interestingly, short-term, mild oxidative stress leads to the nuclear export of TERT with a concomitant increase of its levels outside the nucleus [156], possibly in the mitochondria as a mechanism to preserve their functionality. However, prolonged exposure of endothelial cells to ROS or to high doses thereof, which results in mitochondrial dysfunction, induces TERT loss in these organelles. Intriguingly, this downregulation and nuclear export of TERT are both mediated by Src kinase, which-like other kinases and phosphatases regulating TERT—is also present in mitochondria [157]. 
Although mitochondrial localization of TERT and pathways regulating its levels in these organelles have also been described in the cardiovascular system, it was for the longest time impossible to distinguish between nuclear and mitochondrial functions of TERT. The analysis of mitochondrial functions in TERT-deficient animals, as well as the overexpression of nuclear or mitochondrially targeted TERT, can only provide circumstantial evidence for the functions in the two compartments, as they rely either on the complete absence of the protein or are performed on a background of endogenous TERT, which is present in both organelles.

The first study unequivocally differentiating between nuclear and mitochondrial functions of TERT in vivo and ex vivo made use of unique new mouse models containing TERT in all organs exclusively in either of the two cellular compartments $[158,159]$. With these mice, it was shown that only mitochondrial, but not nuclear TERT, protects against the adverse outcomes after ischemia and reperfusion injury without affecting telomere length. Animals containing TERT only in the mitochondria (mitoTERT mice) have reduced infarct and scar sizes, show improvements in vascularization in the border zone, the region adjacent to the infarct, and in cardiac functions. On the cellular level, the protective effects of mitochondrial TERT are not restricted to cardiomyocytes, which are protected against apoptosis by mitochondrial TERT but also affect the other parental cell types in the heart, namely endothelial cells and cardiac fibroblasts. Mitochondrial TERT improves the migratory capacity of endothelial cells, which is required for enhanced vascularization in the infarct area. Furthermore, mitochondrial TERT improves the differentiation of cardiac fibroblasts into myofibroblasts, a mechanically strong cell type that can passively participate in heart contractions and is necessary to replace dead cardiomyocytes in the early phase after an infarction to form a stable scar. Mechanistically, mitochondrial TERT reduces the amount of mitochondrial Prohibitin, which — when in excess-stabilizes free matrix arm subunits of complex I of the mitochondrial respiratory chain, resulting in increased superoxide production. This reduction in Prohibitin levels, together with an improved stoichiometry between the different subunits of complex I, also explains the enhanced complex I activity in heart mitochondria from the mitoTERT animals [159].

This clear demonstration of protective functions of mitochondrial TERT in myocardial infarction suggests that a therapeutic increase in mitochondrial TERT would be beneficial in cardiovascular diseases. The Telomerase activator TA-65 has already been shown to be safe for humans [160], and it has been demonstrated ex vivo that treatment with this compound leads to increased TERT levels in mitochondria as well as enhanced endothelial cell migration and myofibroblast differentiation of cardiac fibroblasts [159]. TA-65 is currently tested in a clinical trial in patients with acute coronary syndrome [161], which will potentially reveal protective effects in humans.

\section{Conclusions}

In the past years, an understanding of the biochemical processes underlying the mitochondrial preprotein import has progressed substantially, in particular also in mammalian cells. As we show above, dysfunction of mitochondrial preprotein import is correlated with or may result in severe neurodegenerative and cardiovascular pathologies. These observations corroborate the important role mitochondria play in the general maintenance of cellular function. Although mitochondrial preprotein import as such is essential for the survival of any cell, past experiments have indicated several different biochemical mechanisms how import defects contribute to disease-from a simple lack of necessary enzymatic components and the subsequent failure to provide energy to the cell up to the import system as a sensor for underlying mitochondrial dysfunction. Unfortunately, the number of corresponding experiments still remains limited, and there are significant contradictions among published ones. Future experimental studies are required to establish a more detailed and reliable mechanistic understanding of how defective mitochondrial protein import is involved in the respective diseases. In addition, these new insights have to be translated into novel therapeutic approaches to develop respective pharmacological 
treatments. Although many different strategies and drugs to target mitochondria have been suggested, for example, for Alzheimer's disease, therapy efficient treatments are not available to date [90]. In particular, there are no drugs on the market directly targeting the import machinery, so more thorough fundamental studies are urgently required for the progress in this field. Moreover, one has to keep in mind that new mouse models are needed to understand the import machinery in age-related neurodegenerative and cardiovascular diseases.

Author Contributions: Writing-original draft preparation, A.B., I.O., D.B., P.J., W.V., J.A. and J.H.; writing—review and editing, A.B., I.O., D.B., P.J., I.M., V.G., N.A.D., T.G., W.V., J.A., J.H. and V.B.; visualization, A.B., I.O., D.B., J.A. and J.H.; supervision, W.V., J.A., J.H. and V.B; funding acquisition, V.G., T.G., J.A., J.H. and V.B. All authors have read and agreed to the published version of the manuscript.

Funding: This work was supported by RFBR (No: 20-54-12010). V.B., V.G., and I.O. acknowledge the Ministry of Science and Higher Education of the Russian Federation (agreement \# 075-00337-20-03, project FSMG-2020-0003). The AD part of the work is supported by RFBR (I.O. and N.D., No: 20-01500526). J.H. and J.A. acknowledge DFG (grant numbers HA2868/14-1 and SFB1116 A04 and grant numbers AL288/5-1 and SFB1116 A04, respectively).

Institutional Review Board Statement: Not applicable.

Informed Consent Statement: Not applicable.

Conflicts of Interest: The authors declare no conflict of interest.

\section{References}

1. Pfanner, N.; Warscheid, B.; Wiedemann, N. Mitochondrial Proteins: From Biogenesis to Functional Networks. Nat. Rev. Mol. Cell Biol. 2019, 20, 267-284. [CrossRef] [PubMed]

2. Harman, D. The Free Radical Theory of Aging. Antioxid. Redox Signal. 2003, 5, 557-561. [CrossRef]

3. Park, C.B.; Larsson, N.-G. Mitochondrial DNA Mutations in Disease and Aging. J. Cell Biol. 2011, 193, 809-818. [CrossRef] [PubMed]

4. Paradies, G.; Ruggiero, F.M.; Petrosillo, G.; Quagliariello, E. Age-Dependent Decline in the Cytochrome c Oxidase Activity in Rat Heart Mitochondria: Role of Cardiolipin. FEBS Lett. 1997, 406, 136-138. [CrossRef]

5. Garcia-Euiz, C.; Mari, M.; Coiell, A.; Morales, A.; Caballero, F.; Montero, J.; Terrones, O.; Basañes, G.; Fernandez-Checa, J.C. Mitochondrial Cholesterol in Health and Disease. Histol. Histopathol. 2009, 24, 117-132. [CrossRef]

6. Weidling, I.W.; Swerdlow, R.H. Mitochondria in Alzheimer's Disease and Their Potential Role in Alzheimer's Proteostasis. Exp. Neurol. 2020, 330, 113-321. [CrossRef]

7. Voos, W. Chaperone-Protease Networks in Mitochondrial Protein Homeostasis. Biochim. Biophys. Acta-Mol. Cell Res. 2013, 1833, 388-399. [CrossRef]

8. Quirós, P.M.; Langer, T.; López-Otín, C. New Roles for Mitochondrial Proteases in Health, Ageing and Disease. Nat. Rev. Mol. Cell Biol. 2015, 16, 345-359. [CrossRef]

9. Cenini, G.; Voos, W. Role of Mitochondrial Protein Quality Control in Oxidative Stress-Induced Neurodegenerative Diseases. Curr. Alzheimer Res. 2016, 13, 164-173. [CrossRef]

10. Rüb, C.; Wilkening, A.; Voos, W. Mitochondrial Quality Control by the Pink1/Parkin System. Cell Tissue Res. 2017, 367, 111-123. [CrossRef] [PubMed]

11. Hou, Y.; Dan, X.; Babbar, M.; Wei, Y.; Hasselbalch, S.G.; Croteau, D.L.; Bohr, V.A. Ageing as a Risk Factor for Neurodegenerative Disease. Nat. Rev. Neurol. 2019, 15, 565-581. [CrossRef]

12. Green, D.R.; Van Houten, B. SnapShot: Mitochondrial Quality Control. Cell 2011, 147, 950-950.e1. [CrossRef]

13. Wallace, D.C. A Mitochondrial Paradigm of Metabolic and Degenerative Diseases, Aging, and Cancer: A Dawn for Evolutionary Medicine. Annu. Rev. Genet. 2005, 39, 359-407. [CrossRef]

14. Simon, D.K.; Johns, D.R. Mitochondrial Disorders: Clinical and Genetic Features. Annu. Rev. Med. 1999, 50, 111-127. [CrossRef]

15. Van Houten, B.; Woshner, V.; Santos, J.H. Role of Mitochondrial DNA in Toxic Responses to Oxidative Stress. DNA Repair 2006, 5, 145-152. [CrossRef]

16. Wiedemann, N.; Pfanner, N. Mitochondrial Machineries for Protein Import and Assembly. Annu. Rev. Biochem. 2017, 86, 685-714. [CrossRef]

17. Palmer, C.S.; Anderson, A.J.; Stojanovski, D. Mitochondrial Protein Import Dysfunction: Mitochondrial Disease, Neurodegenerative Disease and Cancer. FEBS Lett. 2021, 595, 1107-1131. [CrossRef]

18. Chacinska, A.; Koehler, C.M.; Milenkovic, D.; Lithgow, T.; Pfanner, N. Importing Mitochondrial Proteins: Machineries and Mechanisms. Cell 2009, 138, 628-644. [CrossRef] 
19. Van Kuilenburg, A.B.P.; Muijsers, A.O.; Demol, H.; Dekker, H.L.; Van Beeumen, J.J. Human Heart Cytochrome c Oxidase Subunit VIII Purification and Determination of the Complete Amino Acid Sequence. FEBS Lett. 1988, 240, 127-132. [CrossRef]

20. Pfanner, N.; Hoeben, P.; Tropschug, M.; Neupert, W. The Carboxyl-Terminal Two-Thirds of the ADP/ATP Carrier Polypeptide Contains Sufficient Information to Direct Translocation into Mitochondria. J. Biol. Chem. 1987, 262, 14851-14854. [CrossRef]

21. Jores, T.; Klinger, A.; Groß, L.E.; Kawano, S.; Flinner, N.; Duchardt-Ferner, E.; Wöhnert, J.; Kalbacher, H.; Endo, T.; Schleiff, E.; et al. Characterization of the Targeting Signal in Mitochondrial $\beta$-Barrel Proteins. Nat. Commun. 2016, 7, 12036. [CrossRef]

22. Becker, T.; Song, J.; Pfanner, N. Versatility of Preprotein Transfer from the Cytosol to Mitochondria. Trends Cell Biol. 2019, 29, 534-548. [CrossRef]

23. Vögtle, F.-N.; Wortelkamp, S.; Zahedi, R.P.; Becker, D.; Leidhold, C.; Gevaert, K.; Kellermann, J.; Voos, W.; Sickmann, A.; Pfanner, N.; et al. Global Analysis of the Mitochondrial N-Proteome Identifies a Processing Peptidase Critical for Protein Stability. Cell 2009, 139, 428-439. [CrossRef] [PubMed]

24. Hell, K.; Neupert, W.; Stuart, R.A. Oxa1p Acts as a General Membrane Insertion Machinery for Proteins Encoded by Mitochondrial DNA. EMBO J. 2001, 20, 1281-1288. [CrossRef] [PubMed]

25. Thompson, K.; Mai, N.; Oláhová, M.; Scialó, F.; Formosa, L.E.; Stroud, D.A.; Garrett, M.; Lax, N.Z.; Robertson, F.M.; Jou, C.; et al. OXA 1L Mutations Cause Mitochondrial Encephalopathy and a Combined Oxidative Phosphorylation Defect. EMBO Mol. Med. 2018, 10, e9060. [CrossRef]

26. Fazal, F.M.; Han, S.; Parker, K.R.; Kaewsapsak, P.; Xu, J.; Boettiger, A.N.; Chang, H.Y.; Ting, A.Y. Atlas of Subcellular RNA Localization Revealed by APEX-Seq. Cell 2019, 178, 473-490.e26. [CrossRef]

27. Williams, C.C.; Jan, C.H.; Weissman, J.S. Targeting and Plasticity of Mitochondrial Proteins Revealed by Proximity-Specific Ribosome Profiling. Science 2014, 346, 748-751. [CrossRef]

28. Bogorodskiy, A.; Okhrimenko, I.; Maslov, I.; Maliar, N.; Burkatovskii, D.; von Ameln, F.; Schulga, A.; Jakobs, P.; Altschmied, J.; Haendeler, J.; et al. Accessing Mitochondrial Protein Import in Living Cells by Protein Microinjection. Front. Cell Dev. Biol. 2021, 9, 1794. [CrossRef]

29. Gao, J.; Schatton, D.; Martinelli, P.; Hansen, H.; Pla-Martin, D.; Barth, E.; Becker, C.; Altmueller, J.; Frommolt, P.; Sardiello, M.; et al. CLUH Regulates Mitochondrial Biogenesis by Binding MRNAs of Nuclear-Encoded Mitochondrial Proteins. J. Cell Biol. 2014, 207, 213-223. [CrossRef]

30. Ravanidis, S.; Doxakis, E. RNA-Binding Proteins Implicated in Mitochondrial Damage and Mitophagy. Front. Cell Dev. Biol. 2020, 8, 372. [CrossRef]

31. Qin, W.; Myers, S.A.; Carey, D.K.; Carr, S.A.; Ting, A.Y. Spatiotemporally-Resolved Mapping of RNA Binding Proteins via Functional Proximity Labeling Reveals a Mitochondrial MRNA Anchor Promoting Stress Recovery. Nat. Commun. 2021, 12, 4980. [CrossRef]

32. Shiota, T.; Imai, K.; Qiu, J.; Hewitt, V.L.; Tan, K.; Shen, H.-H.; Sakiyama, N.; Fukasawa, Y.; Hayat, S.; Kamiya, M.; et al. Molecular Architecture of the Active Mitochondrial Protein Gate. Science 2015, 349, 1544-1548. [CrossRef]

33. Guan, Z.; Yan, L.; Wang, Q.; Qi, L.; Hong, S.; Gong, Z.; Yan, C.; Yin, P. Structural Insights into Assembly of Human Mitochondrial Translocase TOM Complex. Cell Discov. 2021, 7, 22. [CrossRef]

34. Kato, H.; Mihara, K. Identification of Tom5 and Tom6 in the Preprotein Translocase Complex of Human Mitochondrial Outer Membrane. Biochem. Biophys. Res. Commun. 2008, 369, 958-963. [CrossRef]

35. Young, J.C.; Hoogenraad, N.J.; Hartl, F.U. Molecular Chaperones Hsp90 and Hsp70 Deliver Preproteins to the Mitochondrial Import Receptor Tom70. Cell 2003, 112, 41-50. [CrossRef]

36. Faou, P.; Hoogenraad, N.J. Tom34: A Cytosolic Cochaperone of the Hsp90/Hsp70 Protein Complex Involved in Mitochondrial Protein Import. Biochim. Biophys. Acta-Mol. Cell Res. 2012, 1823, 348-357. [CrossRef]

37. Juszkiewicz, S.; Hegde, R.S. Quality Control of Orphaned Proteins. Mol. Cell 2018, 71, 443-457. [CrossRef]

38. Armstrong, L.C.; Komiya, T.; Bergman, B.E.; Mihara, K.; Bornstein, P. Metaxin Is a Component of a Preprotein Import Complex in the Outer Membrane of the Mammalian Mitochondrion. J. Biol. Chem. 1997, 272, 6510-6518. [CrossRef]

39. Armstrong, L.C.; Saenz, A.J.; Bornstein, P. Metaxin 1 Interacts with Metaxin 2, a Novel Related Protein Associated with the Mammalian Mitochondrial Outer Membrane. J. Cell. Biochem. 1999, 74, 11-22. [CrossRef]

40. Kozjak-Pavlovic, V.; Ross, K.; Benlasfer, N.; Kimmig, S.; Karlas, A.; Rudel, T. Conserved Roles of Sam50 and Metaxins in VDAC Biogenesis. EMBO Rep. 2007, 8, 576-582. [CrossRef] [PubMed]

41. Dabir, D.V.; Leverich, E.P.; Kim, S.-K.; Tsai, F.D.; Hirasawa, M.; Knaff, D.B.; Koehler, C.M. A Role for Cytochrome c and Cytochrome c Peroxidase in Electron Shuttling from Erv1. EMBO J. 2007, 26, 4801-4811. [CrossRef]

42. Fischer, M.; Horn, S.; Belkacemi, A.; Kojer, K.; Petrungaro, C.; Habich, M.; Ali, M.; Küttner, V.; Bien, M.; Kauff, F.; et al. Protein Import and Oxidative Folding in the Mitochondrial Intermembrane Space of Intact Mammalian Cells. Mol. Biol. Cell 2013, 24, 2160-2170. [CrossRef]

43. Bauer, M.F.; Gempel, K.; Reichert, A.S.; Rappold, G.A.; Lichtner, P.; Gerbitz, K.-D.; Neupert, W.; Brunner, M.; Hofmann, S. Genetic and Structural Characterization of the Human Mitochondrial Inner Membrane Translocase 1 1Edited by J. Karn. J. Mol. Biol. 1999, 289, 69-82. [CrossRef]

44. Sinha, D.; Srivastava, S.; Krishna, L.; D'Silva, P. Unraveling the Intricate Organization of Mammalian Mitochondrial Presequence Translocases: Existence of Multiple Translocases for Maintenance of Mitochondrial Function. Mol. Cell. Biol. 2014, 34, 1757-1775. [CrossRef] 
45. Sokol, A.M.; Sztolsztener, M.E.; Wasilewski, M.; Heinz, E.; Chacinska, A. Mitochondrial Protein Translocases for Survival and Wellbeing. FEBS Lett. 2014, 588, 2484-2495. [CrossRef]

46. Curran, S.P.; Leuenberger, D.; Schmidt, E.; Koehler, C.M. The Role of the Tim8p-Tim13p Complex in a Conserved Import Pathway for Mitochondrial Polytopic Inner Membrane Proteins. J. Cell Biol. 2002, 158, 1017-1027. [CrossRef]

47. Bauer, M.F.; Rothbauer, U.; Mühlenbein, N.; Smith, R.J.H.; Gerbitz, K.-D.; Neupert, W.; Brunner, M.; Hofmann, S. The Mitochondrial TIM22 Preprotein Translocase Is Highly Conserved throughout the Eukaryotic Kingdom. FEBS Lett. 1999, 464, 41-47. [CrossRef]

48. Qi, L.; Wang, Q.; Guan, Z.; Wu, Y.; Shen, C.; Hong, S.; Cao, J.; Zhang, X.; Yan, C.; Yin, P. Cryo-EM Structure of the Human Mitochondrial Translocase TIM22 Complex. Cell Res. 2021, 31, 369-372. [CrossRef]

49. Kang, Y.; Stroud, D.A.; Baker, M.J.; De Souza, D.P.; Frazier, A.E.; Liem, M.; Tull, D.; Mathivanan, S.; McConville, M.J.; Thorburn, D.R.; et al. Sengers Syndrome-Associated Mitochondrial Acylglycerol Kinase Is a Subunit of the Human TIM22 Protein Import Complex. Mol. Cell 2017, 67, 457-470.e5. [CrossRef]

50. Kang, Y.; Baker, M.J.; Liem, M.; Louber, J.; McKenzie, M.; Atukorala, I.; Ang, C.S.; Keerthikumar, S.; Mathivanan, S.; Stojanovski, D. Tim29 Is a Novel Subunit of the Human TIM22 Translocase and Is Involved in Complex Assembly and Stability. eLife 2016, 5, e17463. [CrossRef]

51. Mejia, E.M.; Hatch, G.M. Mitochondrial Phospholipids: Role in Mitochondrial Function. J. Bioenerg. Biomembr. 2016, 48, 99-112. [CrossRef]

52. Gasanoff, E.S.; Yaguzhinsky, L.S.; Garab, G. Cardiolipin, Non-Bilayer Structures and Mitochondrial Bioenergetics: Relevance to Cardiovascular Disease. Cells 2021, 10, 1721. [CrossRef]

53. Osman, C.; Voelker, D.R.; Langer, T. Making Heads or Tails of Phospholipids in Mitochondria. J. Cell Biol. 2011, 192, 7-16. [CrossRef]

54. Gebert, N.; Joshi, A.S.; Kutik, S.; Becker, T.; McKenzie, M.; Guan, X.L.; Mooga, V.P.; Stroud, D.A.; Kulkarni, G.; Wenk, M.R.; et al. Mitochondrial Cardiolipin Involved in Outer-Membrane Protein Biogenesis: Implications for Barth Syndrome. Curr. Biol. 2009, 19, 2133-2139. [CrossRef]

55. Haines, T.H.; Dencher, N.A. Cardiolipin: A Proton Trap for Oxidative Phosphorylation. FEBS Lett. 2002, 528, 35-39. [CrossRef]

56. Malhotra, K.; Modak, A.; Nangia, S.; Daman, T.H.; Gunsel, U.; Robinson, V.L.; Mokranjac, D.; May, E.R.; Alder, N.N. Cardiolipin Mediates Membrane and Channel Interactions of the Mitochondrial TIM23 Protein Import Complex Receptor Tim50. Sci. Adv. 2017, 3, e1700532. [CrossRef]

57. Elustondo, P.; Martin, L.A.; Karten, B. Mitochondrial Cholesterol Import. Biochim. Biophys. Acta-Mol. Cell Biol. Lipids 2017, 1862, 90-101. [CrossRef]

58. Martin, L.A.; Kennedy, B.E.; Karten, B. Mitochondrial Cholesterol: Mechanisms of Import and Effects on Mitochondrial Function. J. Bioenerg. Biomembr. 2016, 48, 137-151. [CrossRef]

59. Bose, H.S.; Lingappa, V.R.; Miller, W.L. Rapid Regulation of Steroidogenesis by Mitochondrial Protein Import. Nature 2002, 417, 87-91. [CrossRef]

60. Lin, M.T.; Beal, M.F. Mitochondrial Dysfunction and Oxidative Stress in Neurodegenerative Diseases. Nature 2006, 443, 787-795. [CrossRef] [PubMed]

61. Poewe, W.; Seppi, K.; Tanner, C.M.; Halliday, G.M.; Brundin, P.; Volkmann, J.; Schrag, A.E.; Lang, A.E. Parkinson Disease. Nat. Rev. Dis. Prim. 2017, 3, 1-21. [CrossRef]

62. Pacelli, C.; Giguère, N.; Bourque, M.J.; Lévesque, M.; Slack, R.S.; Trudeau, L.É. Elevated Mitochondrial Bioenergetics and Axonal Arborization Size Are Key Contributors to the Vulnerability of Dopamine Neurons. Curr. Biol. 2015, 25, 2349-2360. [CrossRef] [PubMed]

63. Puschmann, A. Monogenic Parkinson's Disease and Parkinsonism: Clinical Phenotypes and Frequencies of Known Mutations. Parkinsonism Relat. Disord. 2013, 19, 407-415. [CrossRef] [PubMed]

64. Greene, A.W.; Grenier, K.; Aguileta, M.A.; Muise, S.; Farazifard, R.; Haque, M.E.; McBride, H.M.; Park, D.S.; Fon, E.A. Mitochondrial Processing Peptidase Regulates PINK1 Processing, Import and Parkin Recruitment. EMBO Rep. 2012, 13, 378-385. [CrossRef]

65. Takatori, S.; Ito, G.; Iwatsubo, T. Cytoplasmic Localization and Proteasomal Degradation of N-Terminally Cleaved Form of PINK1. Neurosci. Lett. 2008, 430, 13-17. [CrossRef] [PubMed]

66. Okatsu, K.; Uno, M.; Koyano, F.; Go, E.; Kimura, M.; Oka, T.; Tanaka, K.; Matsuda, N. A Dimeric Pink1-Containing Complex on Depolarized Mitochondria Stimulates Parkin Recruitment. J. Biol. Chem. 2013, 288, 36372-36384. [CrossRef] [PubMed]

67. Kane, L.A.; Lazarou, M.; Fogel, A.I.; Li, Y.; Yamano, K.; Sarraf, S.A.; Banerjee, S.; Youle, R.J. PINK1 Phosphorylates Ubiquitin to Activate Parkin E3 Ubiquitin Ligase Activity. J. Cell Biol. 2014, 205, 143-153. [CrossRef] [PubMed]

68. Tanaka, A.; Cleland, M.M.; Xu, S.; Narendra, D.P.; Suen, D.F.; Karbowski, M.; Youle, R.J. Proteasome and P97 Mediate Mitophagy and Degradation of Mitofusins Induced by Parkin. J. Cell Biol. 2010, 191, 1367-1380. [CrossRef] [PubMed]

69. Sekine, S.; Youle, R.J. PINK1 Import Regulation; a Fine System to Convey Mitochondrial Stress to the Cytosol. BMC Biol. 2018, 16, 1-13. [CrossRef]

70. Hasson, S.A.; Kane, L.A.; Yamano, K.; Huang, C.H.; Sliter, D.A.; Buehler, E.; Wang, C.; Heman-Ackah, S.M.; Hessa, T.; Guha, R.; et al. High-Content Genome-Wide RNAi Screens Identify Regulators of Parkin Upstream of Mitophagy. Nature 2013, 504, 291-295. [CrossRef] 
71. Lazarou, M.; Jin, S.M.; Kane, L.A.; Youle, R.J. Role of PINK1 Binding to the TOM Complex and Alternate Intracellular Membranes in Recruitment and Activation of the E3 Ligase Parkin. Dev. Cell 2012, 22, 320-333. [CrossRef]

72. Gehrke, S.; Wu, Z.; Klinkenberg, M.; Sun, Y.; Auburger, G.; Guo, S.; Lu, B. PINK1 and Parkin Control Localized Translation of Respiratory Chain Component MRNAs on Mitochondria Outer Membrane. Physiol. Behav. 2018, 176, 139-148. [CrossRef]

73. Kasten, M.; Hartmann, C.; Hampf, J.; Schaake, S.; Westenberger, A.; Vollstedt, E.-J.; Balck, A.; Domingo, A.; Vulinovic, F.; Dulovic, M.; et al. Genotype-Phenotype Relations for the Parkinson's Disease Genes Parkin, PINK1, DJ1: MDSGene Systematic Review. Mov. Disord. 2018, 33, 730-741. [CrossRef] [PubMed]

74. Ando, M.; Fiesel, F.C.; Hudec, R.; Caulfield, T.R.; Ogaki, K.; Górka-Skoczylas, P.; Koziorowski, D.; Friedman, A.; Chen, L.; Dawson, V.L.; et al. The PINK1 p.I368N Mutation Affects Protein Stability and Ubiquitin Kinase Activity. Mol. Neurodegener. $2017,12,32$. [CrossRef] [PubMed]

75. Beilina, A.; Van Der Brug, M.; Ahmad, R.; Kesavapany, S.; Miller, D.W.; Petsko, G.A.; Cookson, M.R. Mutations in PTEN-Induced Putative Kinase 1 Associated with Recessive Parkinsonism Have Differential Effects on Protein Stability. Proc. Natl. Acad. Sci. USA 2005, 102, 5703-5708. [CrossRef] [PubMed]

76. Puschmann, A.; Fiesel, F.C.; Caulfield, T.R.; Hudec, R.; Ando, M.; Truban, D.; Hou, X.; Ogaki, K.; Heckman, M.G.; James, E.D.; et al. Heterozygous PINK1 p.G411S Increases Risk of Parkinson's Disease via a Dominant-Negative Mechanism. Brain 2017, 140, 98-117. [CrossRef] [PubMed]

77. Gu, W.-J.; Corti, O.; Araujo, F.; Hampe, C.; Jacquier, S.; Lücking, C.B.; Abbas, N.; Duyckaerts, C.; Rooney, T.; Pradier, L.; et al. The C289G and C418R Missense Mutations Cause Rapid Sequestration of Human Parkin into Insoluble Aggregates. Neurobiol. Dis. 2003, 14, 357-364. [CrossRef] [PubMed]

78. Matsuda, N.; Kitami, T.; Suzuki, T.; Mizuno, Y.; Hattori, N.; Tanaka, K. Diverse Effects of Pathogenic Mutations of Parkin That Catalyze Multiple Monoubiquitylation in Vitro. J. Biol. Chem. 2006, 281, 3204-3209. [CrossRef]

79. Di Maio, R.; Barrett, P.J.; Hoffman, E.K.; Barrett, C.W.; Zharikov, A.; Borah, A.; Hu, X.; McCoy, J.; Chu, C.T.; Burton, E.A.; et al. $\alpha$-Synuclein Binds to TOM20 and Inhibits Mitochondrial Protein Import in Parkinson's Disease. Sci. Transl. Med. 2016. [CrossRef] [PubMed]

80. Bender, A.; Desplats, P.; Spencer, B.; Rockenstein, E.; Adame, A.; Elstner, M.; Laub, C.; Mueller, S.; Koob, A.O.; Mante, M.; et al. TOM40 Mediates Mitochondrial Dysfunction Induced by $\alpha$-Synuclein Accumulation in Parkinson's Disease. PLoS ONE 2013, 8 , e62277. [CrossRef] [PubMed]

81. Devi, L.; Raghavendran, V.; Prabhu, B.M.; Avadhani, N.G.; Anandatheerthavarada, H.K. Mitochondrial Import and Accumulation of $\alpha$-Synuclein Impair Complex I in Human Dopaminergic Neuronal Cultures and Parkinson Disease Brain. J. Biol. Chem. 2008, 283, 9089-9100. [CrossRef] [PubMed]

82. Rovini, A.; Gurnev, P.A.; Beilina, A.; Queralt-Martín, M.; Rosencrans, W.; Cookson, M.R.; Bezrukov, S.M.; Rostovtseva, T.K. Molecular Mechanism of Olesoxime-Mediated Neuroprotection through Targeting $\alpha$-Synuclein Interaction with Mitochondrial VDAC. Cell. Mol. Life Sci. 2020, 77, 3611-3626. [CrossRef] [PubMed]

83. Rostovtseva, T.K.; Gurnev, P.A.; Protchenko, O.; Hoogerheide, D.P.; Yap, T.L.; Philpott, C.C.; Lee, J.C.; Bezrukov, S.M. $\alpha$-Synuclein Shows High Affinity Interaction with Voltage-Dependent Anion Channel, Suggesting Mechanisms of Mitochondrial Regulation and Toxicity in Parkinson Disease. J. Biol. Chem. 2015, 290, 18467-18477. [CrossRef] [PubMed]

84. 2019 Alzheimer's Disease Facts and Figures. Alzheimer's Dement. 2019, 15, 321-387. [CrossRef]

85. Stelzmann, R.A.; Norman Schnitzlein, H.; Reed Murtagh, F. An English Translation of Alzheimer's 1907 Paper, “Uber Eine Eigenartige Erkankung Der Hirnrinde". Clin. Anat. 1995, 8, 429-431. [CrossRef] [PubMed]

86. Hardy, J. Alzheimer's Disease: The Amyloid Cascade Hypothesis: An Update and Reappraisal. J. Alzheimer's Dis. 2006,9 , $151-153$. [CrossRef] [PubMed]

87. Gouras, G.K.; Tsai, J.; Naslund, J.; Vincent, B.; Edgar, M.; Checler, F.; Greenfield, J.P.; Haroutunian, V.; Buxbaum, J.D.; Xu, H.; et al. Intraneuronal A $\beta 42$ Accumulation in Human Brain. Am. J. Pathol. 2000, 156, 15-20. [CrossRef]

88. Gouras, G.K.; Tampellini, D.; Takahashi, R.H.; Capetillo-Zarate, E. Intraneuronal $\beta$-Amyloid Accumulation and Synapse Pathology in Alzheimer's Disease. Acta Neuropathol. 2010, 119, 523-541. [CrossRef] [PubMed]

89. Friedrich, R.P.; Tepper, K.; Rönicke, R.; Soom, M.; Westermann, M.; Reymann, K.; Kaether, C.; Fändrich, M. Mechanism of Amyloid Plaque Formation Suggests an Intracellular Basis of A $\beta$ Pathogenicity. Proc. Natl. Acad. Sci. USA 2010, 107, $1942-1947$. [CrossRef]

90. Cenini, G.; Voos, W. Mitochondria as Potential Targets in Alzheimer Disease Therapy: An Update. Front. Pharmacol. 2019, 10, 902. [CrossRef] [PubMed]

91. Swerdlow, R.H.; Burns, J.M.; Khan, S.M. The Alzheimer's Disease Mitochondrial Cascade Hypothesis: Progress and Perspectives. Biochim. Biophys. Acta-Mol. Basis Dis. 2014, 1842, 1219-1231. [CrossRef]

92. Narayan, P.; Holmström, K.M.; Kim, D.-H.; Whitcomb, D.J.; Wilson, M.R.; St. George-Hyslop, P.; Wood, N.W.; Dobson, C.M.; Cho, K.; Abramov, A.Y.; et al. Rare Individual Amyloid- $\beta$ Oligomers Act on Astrocytes to Initiate Neuronal Damage. Biochemistry 2014, 53, 2442-2453. [CrossRef]

93. Džinić, T.; Dencher, N.A. Oxygen Concentration and Oxidative Stress Modulate the Influence of Alzheimer's Disease A $\beta$ 1-42 Peptide on Human Cells. Oxid. Med. Cell. Longev. 2018, 2018, 1-16. [CrossRef] [PubMed] 
94. Dencher, N.A.; Bogorodskiy, A.O.; Borshchevskiy, V.I.; Gordeliy, V.I.; Malyar, N.L.; Maslov, I.V.; Okhrimenko, I.S.; Podolyak, E.Y.; Dani, D.D.V.; Dzinic, T.; et al. Challenge the "Free Radical Theory of Ageing" and the Aß Peptide Extracellular Plaque Hypothesis of Alzheimer's Disease. In Proceedings of the Biomembranes 2018, Dolgoprudny, Russian, 15 December 2018; Volume 50, pp. 467-603.

95. Devi, L. Accumulation of Amyloid Precursor Protein in the Mitochondrial Import Channels of Human Alzheimer's Disease Brain Is Associated with Mitochondrial Dysfunction. J. Neurosci. 2006, 26, 9057-9068. [CrossRef] [PubMed]

96. Anandatheerthavarada, H.K.; Biswas, G.; Robin, M.-A.; Avadhani, N.G. Mitochondrial Targeting and a Novel Transmembrane Arrest of Alzheimer's Amyloid Precursor Protein Impairs Mitochondrial Function in Neuronal Cells. J. Cell Biol. 2003, 161, 41-54. [CrossRef]

97. Anandatheerthavarada, H.K.; Devi, L. Mitochondrial Translocation of Amyloid Precursor Protein and Its Cleaved Products: Relevance to Mitochondrial Dysfunction in Alzheimer's Disease. Rev. Neurosci. 2007, 18, 343-354. [CrossRef]

98. Cenini, G.; Rüb, C.; Bruderek, M.; Voos, W. Amyloid $\beta$-Peptides Interfere with Mitochondrial Preprotein Import Competence by a Coaggregation Process. Mol. Biol. Cell 2016, 27, 3257-3272. [CrossRef] [PubMed]

99. Pagani, L.; Eckert, A. Amyloid-Beta Interaction with Mitochondria. Int. J. Alzheimers. Dis. 2011, 2011, 1-12. [CrossRef]

100. Harbauer, A.B.; Zahedi, R.P.; Sickmann, A.; Pfanner, N.; Meisinger, C. The Protein Import Machinery of Mitochondria-A Regulatory Hub in Metabolism, Stress, and Disease. Cell Metab. 2014, 19, 357-372. [CrossRef]

101. Klingenberg, M.; Rrottenberg, H. Relation between the Gradient of the ATP/ADP Ratio and the Membrane Potential across the Mitochondrial Membrane. Eur. J. Biochem. 1977, 73, 125-130. [CrossRef] [PubMed]

102. Liberman, E.A.; Topaly, V.P.; Tsofina, L.M.; Jasaitis, A.A.; Skulachev, V.P. Mechanism of Coupling of Oxidative Phosphorylation and the Membrane Potential of Mitochondria. Nature 1969, 222, 1076-1078. [CrossRef]

103. Wiedemann, N.; van der Laan, M.; Hutu, D.P.; Rehling, P.; Pfanner, N. Sorting Switch of Mitochondrial Presequence Translocase Involves Coupling of Motor Module to Respiratory Chain. J. Cell Biol. 2007, 179, 1115-1122. [CrossRef]

104. Teo, E.; Ravi, S.; Barardo, D.; Kim, H.S.; Fong, S.; Gassiot, A.C.; Tan, T.Y.; Ching, J.; Kovalik, J.P.; Wenk, M.R.; et al. Metabolic Stress Is a Primary Pathogenic Event in Transgenic Caenorhabditis Elegans Expressing Pan-Neuronal Human Amyloid Beta. eLife 2019, 8, e50069. [CrossRef]

105. Lehninger, A.L. Proton and Electric Charge Translocation in Mitochondrial Energy Transduction BT-Structure and Function Relationships in Biochemical Systems. In Structure and Function Relationships in Biochemical Systems; Bossa, F., Chiancone, E., Finazzi-Agrò, A., Strom, R., Eds.; Springer: Boston, MA, USA, 1982; pp. 171-186. ISBN 978-1-4615-9281-5.

106. Skulachev, V.P. Mitochondrial Physiology and Pathology; Concepts of Programmed Death of Organelles, Cells and Organisms. Mol. Aspects Med. 1999, 20, 139-184. [CrossRef]

107. Lejri, I.; Agapouda, A.; Grimm, A.; Eckert, A. Mitochondria- and Oxidative Stress-Targeting Substances in Cognitive DeclineRelated Disorders: From Molecular Mechanisms to Clinical Evidence. Oxid. Med. Cell. Longev. 2019, 2019, 1-26. [CrossRef]

108. Del Prete, D.; Suski, J.M.; Oulès, B.; Debayle, D.; Gay, A.S.; Lacas-Gervais, S.; Bussiere, R.; Bauer, C.; Pinton, P.; Paterlini-Bréchot, P.; et al. Localization and Processing of the Amyloid- $\beta$ Protein Precursor in Mitochondria-Associated Membranes. J. Alzheimer's Dis. 2016, 55, 1549-1570. [CrossRef]

109. Urban, A.S.; Pavlov, K.V.; Kamynina, A.V.; Okhrimenko, I.S.; Arseniev, A.S.; Bocharov, E.V. Structural Studies Providing Insights into Production and Conformational Behavior of Amyloid- $\beta$ Peptide Associated with Alzheimer's Disease Development. Molecules 2021, 26, 2897. [CrossRef]

110. Yamaguchi, H.; Yamazaki, T.; Ishiguro, K.; Shoji, M.; Nakazato, Y.; Hirai, S. Ultrastructural Localization of Alzheimer Amyloid Beta/A4 Protein Precursor in the Cytoplasm of Neurons and Senile Plaque-Associated Astrocytes. Acta Neuropathol. 1992, 85, 15-22. [CrossRef]

111. Pavlov, P.F.; Wiehager, B.; Sakai, J.; Frykman, S.; Behbahani, H.; Winblad, B.; Ankarcrona, M. Mitochondrial $\Gamma$-secretase Participates in the Metabolism of Mitochondria-associated Amyloid Precursor Protein. FASEB J. 2011, 25, 78-88. [CrossRef]

112. Hansson, C.A.; Frykman, S.; Farmery, M.R.; Tjernberg, L.O.; Nilsberth, C.; Pursglove, S.E.; Ito, A.; Winblad, B.; Cowburn, R.F.; Thyberg, J.; et al. Nicastrin, Presenilin, APH-1, and PEN-2 Form Active $\gamma$-Secretase Complexes in Mitochondria. J. Biol. Chem. 2004, 279, 51654-51660. [CrossRef]

113. Nowicka, U.; Chroscicki, P.; Stroobants, K.; Sladowska, M.; Turek, M.; Uszczynska-Ratajczak, B.; Kundra, R.; Goral, T.; Perni, M.; Dobson, C.M.; et al. Cytosolic Aggregation of Mitochondrial Proteins Disrupts Cellular Homeostasis by Stimulating the Aggregation of Other Proteins. eLife 2021, 10, e65484. [CrossRef]

114. Sirk, D.; Zhu, Z.; Wadia, J.S.; Shulyakova, N.; Phan, N.; Fong, J.; Mills, L.R. Chronic Exposure to Sub-Lethal Beta-Amyloid (A $\beta$ ) Inhibits the Import of Nuclear-Encoded Proteins to Mitochondria in Differentiated PC12 Cells. J. Neurochem. 2007, 103, 1989-2003. [CrossRef]

115. Istrate, A.N.; Kozin, S.A.; Zhokhov, S.S.; Mantsyzov, A.B.; Kechko, O.I.; Pastore, A.; Makarov, A.A.; Polshakov, V.I. Interplay of Histidine Residues of the Alzheimer's Disease A $\beta$ Peptide Governs Its Zn-Induced Oligomerization. Sci. Rep. 2016, 6, 21734. [CrossRef] [PubMed]

116. Hansson Petersen, C.A.; Alikhani, N.; Behbahani, H.; Wiehager, B.; Pavlov, P.F.; Alafuzoff, I.; Leinonen, V.; Ito, A.; Winblad, B.; Glaser, E.; et al. The Amyloid $\beta$-Peptide Is Imported into Mitochondria via the TOM Import Machinery and Localized to Mitochondrial Cristae. Proc. Natl. Acad. Sci. USA 2008, 105, 13145-13150. [CrossRef] 
117. Tillement, L.; Lecanu, L.; Yao, W.; Greeson, J.; Papadopoulos, V. The Spirostenol (22R, 25R)-20 $\alpha$-Spirost-5-En-3 $\beta$-Yl Hexanoate Blocks Mitochondrial Uptake of $\mathrm{A} \beta$ in Neuronal Cells and Prevents $\mathrm{A} \beta$-Induced Impairment of Mitochondrial Function. Steroids 2006, 71, 725-735. [CrossRef]

118. Falkevall, A.; Alikhani, N.; Bhushan, S.; Pavlov, P.F.; Busch, K.; Johnson, K.A.; Eneqvist, T.; Tjernberg, L.; Ankarcrona, M.; Glaser, E. Degradation of the Amyloid $\beta$-Protein by the Novel Mitochondrial Peptidasome, PreP. J. Biol. Chem. 2006, 281, 29096-29104. [CrossRef] [PubMed]

119. Mossmann, D.; Vögtle, F.-N.; Taskin, A.A.; Teixeira, P.F.; Ring, J.; Burkhart, J.M.; Burger, N.; Pinho, C.M.; Tadic, J.; Loreth, D.; et al. Amyloid- $\beta$ Peptide Induces Mitochondrial Dysfunction by Inhibition of Preprotein Maturation. Cell Metab. 2014, 20 , 662-669. [CrossRef]

120. Pinho, C.M.; Teixeira, P.F.; Glaser, E. Mitochondrial Import and Degradation of Amyloid- $\beta$ Peptide. Biochim. Biophys. Acta-Bioenerg. 2014, 1837, 1069-1074. [CrossRef]

121. Fang, D.; Wang, Y.; Zhang, Z.; Du, H.; Yan, S.; Sun, Q.; Zhong, C.; Wu, L.; Vangavaragu, J.R.; Yan, S.; et al. Increased Neuronal PreP Activity Reduces A $\beta$ Accumulation, Attenuates Neuroinflammation and Improves Mitochondrial and Synaptic Function in Alzheimer Disease's Mouse Model. Hum. Mol. Genet. 2015, 24, 5198-5210. [CrossRef]

122. Ostermann, J.; Voos, W.; Kang, P.J.; Craig, E.A.; Neupert, W.; Pfanner, N. Precursor Proteins in Transit through Mitochondrial Contact Sites Interact with Hsp70 in the Matrix. FEBS Lett. 1990, 277, 281-284. [CrossRef]

123. Horst, M. Sequential Action of Two Hsp70 Complexes during Protein Import into Mitochondria. EMBO J. 1997, 16, 1842-1849. [CrossRef]

124. Park, S.J.; Shin, J.H.; Jeong, J.I.; Song, J.H.; Jo, Y.K.; Kim, E.S.; Lee, E.H.; Hwang, J.J.; Lee, E.K.; Chung, S.J.; et al. Down-Regulation of Mortalin Exacerbates A $\beta$-Mediated Mitochondrial Fragmentation and Dysfunction. J. Biol. Chem. 2014, 289, $2195-2204$. [CrossRef]

125. Deocaris, C.C.; Kaul, S.C.; Wadhwa, R. From Proliferative to Neurological Role of an Hsp70 Stress Chaperone, Mortalin. Biogerontology 2008, 9, 391-403. [CrossRef]

126. Zhou, R.; Yang, G.; Guo, X.; Zhou, Q.; Lei, J.; Shi, Y. Recognition of the Amyloid Precursor Protein by Human $\gamma$-Secretase. Science 2019, 363, 6428. [CrossRef]

127. Nierzwicki, Ł.; Olewniczak, M.; Chodnicki, P.; Czub, J. Role of Cholesterol in Substrate Recognition by $\gamma$-Secretase. Sci. Rep. 2021, 11, 15213. [CrossRef]

128. Langness, V.F.; van der Kant, R.; Das, U.; Wang, L.; dos Chaves, R.S.; Goldstein, L.S.B. Cholesterol-Lowering Drugs Reduce APP Processing to A $\beta$ by Inducing APP Dimerization. Mol. Biol. Cell 2021, 32, 247-259. [CrossRef]

129. Barrett, P.J.; Song, Y.; Van Horn, W.D.; Hustedt, E.J.; Schafer, J.M.; Hadziselimovic, A.; Beel, A.J.; Sanders, C.R. The Amyloid Precursor Protein Has a Flexible Transmembrane Domain and Binds Cholesterol. Science 2012, 336, 1168-1171. [CrossRef]

130. Nadezhdin, K.D.; Bocharova, O.V.; Bocharov, E.V.; Arseniev, A.S. Structural and Dynamic Study of the Transmembrane Domain of the Amyloid Precursor Protein. Acta Nat. 2011, 3, 69-76. [CrossRef]

131. Grimm, M.O.W.; Grimm, H.S.; Tomic, I.; Beyreuther, K.; Hartmann, T.; Bergmann, C. Independent Inhibition of Alzheimer Disease $\beta$ - and $\gamma$-Secretase Cleavage by Lowered Cholesterol Levels. J. Biol. Chem. 2008, 283, 11302-11311. [CrossRef]

132. Wang, H.; Kulas, J.A.; Wang, C.; Holtzman, D.M.; Ferris, H.A.; Hansen, S.B. Regulation of Beta-Amyloid Production in Neurons by Astrocyte-Derived Cholesterol. Proc. Natl. Acad. Sci. USA 2021, 118, e2102191118. [CrossRef]

133. Bodovitz, S.; Klein, W.L. Cholesterol Modulates $\alpha$-Secretase Cleavage of Amyloid Precursor Protein. J. Biol. Chem. 1996, 271, 4436-4440. [CrossRef]

134. Montesinos, J.; Pera, M.; Larrea, D.; Guardia-Laguarta, C.; Agrawal, R.R.; Velasco, K.R.; Yun, T.D.; Stavrovskaya, I.G.; Xu, Y.; Koo, S.Y.; et al. The Alzheimer's Disease-associated C99 Fragment of APP Regulates Cellular Cholesterol Trafficking. EMBO J. 2020, 39, e103791. [CrossRef]

135. Kozin, S.A.; Barykin, E.P.; Mitkevich, V.A.; Makarov, A.A. Anti-Amyloid Therapy of Alzheimer's Disease: Current State and Prospects. Biochemistry 2018, 83, 1057-1067. [CrossRef]

136. Bocharov, E.V.; Gremer, L.; Urban, A.S.; Okhrimenko, I.S.; Volynsky, P.E.; Nadezhdin, K.D.; Bocharova, O.V.; Kornilov, D.A.; Zagryadskaya, Y.A.; Kamynina, A.V.; et al. All-d-Enantiomeric Peptide D3 Designed for Alzheimer's Disease Treatment Dynamically Interacts with Membrane-Bound Amyloid- $\beta$ Precursors. J. Med. Chem. 2021, 64, 16464-16479. [CrossRef]

137. Elfgen, A.; Hupert, M.; Bochinsky, K.; Tusche, M.; González de San Román Martin, E.; Gering, I.; Sacchi, S.; Pollegioni, L.; Huesgen, P.F.; Hartmann, R.; et al. Metabolic Resistance of the D-Peptide RD2 Developed for Direct Elimination of Amyloid- $\beta$ Oligomers. Sci. Rep. 2019, 9, 5715. [CrossRef]

138. Timmis, A.; Townsend, N.; Gale, C.P.; Torbica, A.; Lettino, M.; Petersen, S.E.; Mossialos, E.A.; Maggioni, A.P.; Kazakiewicz, D.; May, H.T.; et al. European Society of Cardiology: Cardiovascular Disease Statistics 2019. Eur. Heart J. 2020, 41, 12-85. [CrossRef]

139. Zhao, F.; Zou, M.-H. Role of the Mitochondrial Protein Import Machinery and Protein Processing in Heart Disease. Front. Cardiovasc. Med. 2021, 8, 749756. [CrossRef]

140. International Mouse Phenotyping Consortium. Available online: https:/ /www.mousephenotype.org (accessed on 15 November 2021).

141. Paradies, G.; Petrosillo, G.; Ruggiero, F.M. Cardiolipin-Dependent Decrease of Cytochrome c Oxidase Activity in Heart Mitochondria from Hypothyroid Rats. Biochim. Biophys. Acta-Bioenerg. 1997, 1319, 5-8. [CrossRef]

142. Paradies, G.; Petrosillo, G.; Pistolese, M.; Di Venosa, N.; Federici, A.; Ruggiero, F.M. Decrease in Mitochondrial Complex I Activity in Ischemic/Reperfused Rat Heart. Circ. Res. 2004, 94, 53-59. [CrossRef] 
143. Maekawa, S.; Takada, S.; Nambu, H.; Furihata, T.; Kakutani, N.; Setoyama, D.; Ueyanagi, Y.; Kang, D.; Sabe, H.; Kinugawa, S. Linoleic Acid Improves Assembly of the CII Subunit and CIII2/CIV Complex of the Mitochondrial Oxidative Phosphorylation System in Heart Failure. Cell Commun. Signal. 2019, 17, 128. [CrossRef] [PubMed]

144. El-Hafidi, M.; Correa, F.; Zazueta, C. Mitochondrial Dysfunction in Metabolic and Cardiovascular Diseases Associated with Cardiolipin Remodeling. Biochim. Biophys. Acta-Mol. Basis Dis. 2020, 1866, 165744. [CrossRef]

145. Werner, C.; Hanhoun, M.; Widmann, T.; Kazakov, A.; Semenov, A.; Pöss, J.; Bauersachs, J.; Thum, T.; Pfreundschuh, M.; Müller P.; et al. Effects of Physical Exercise on Myocardial Telomere-Regulating Proteins, Survival Pathways, and Apoptosis. J. Am. Coll. Cardiol. 2008, 52, 470-482. [CrossRef]

146. Werner, C.; Fürster, T.; Widmann, T.; Pöss, J.; Roggia, C.; Hanhoun, M.; Scharhag, J.; Büchner, N.; Meyer, T.; Kindermann, W.; et al. Physical Exercise Prevents Cellular Senescence in Circulating Leukocytes and in the Vessel Wall. Circulation 2009, 120, $2438-2447$. [CrossRef] [PubMed]

147. Richardson, G.D.; Breault, D.; Horrocks, G.; Cormack, S.; Hole, N.; Owens, W.A. Telomerase Expression in the Mammalian Heart. FASEB J. 2012, 26, 4832-4840. [CrossRef] [PubMed]

148. Santos, J.H.; Meyer, J.N.; Skorvaga, M.; Annab, L.A.; Van Houten, B. Mitochondrial HTERT Exacerbates Free-Radical-Mediated MtDNA Damage. Aging Cell 2004, 3, 399-411. [CrossRef]

149. Haendeler, J.; Dröse, S.; Büchner, N.; Jakob, S.; Altschmied, J.; Goy, C.; Spyridopoulos, I.; Zeiher, A.M.; Brandt, U.; Dimmeler, S. Mitochondrial Telomerase Reverse Transcriptase Binds to and Protects Mitochondrial DNA and Function From Damage. Arterioscler. Thromb. Vasc. Biol. 2009, 29, 929-935. [CrossRef]

150. Ahmed, S.; Passos, J.F.; Birket, M.J.; Beckmann, T.; Brings, S.; Peters, H.; Birch-Machin, M.A.; von Zglinicki, T.; Saretzki, G. Telomerase Does Not Counteract Telomere Shortening but Protects Mitochondrial Function under Oxidative Stress. J. Cell Sci. 2008, 121, 1046-1053. [CrossRef] [PubMed]

151. Kovalenko, O.A.; Caron, M.J.; Ulema, P.; Medrano, C.; Thomas, A.P.; Kimura, M.; Bonini, M.G.; Herbig, U.; Santos, J.H. A Mutant Telomerase Defective in Nuclear-Cytoplasmic Shuttling Fails to Immortalize Cells and Is Associated with Mitochondrial Dysfunction. Aging Cell 2010, 9, 203-219. [CrossRef] [PubMed]

152. Beyer, A.M.; Freed, J.K.; Durand, M.J.; Riedel, M.; Ait-Aissa, K.; Green, P.; Hockenberry, J.C.; Morgan, R.G.; Donato, A.J.; Peleg, R.; et al. Critical Role for Telomerase in the Mechanism of Flow-Mediated Dilation in the Human Microcirculation. Circ. Res. 2016, 118, 856-866. [CrossRef]

153. Oh, H.; Taffet, G.E.; Youker, K.A.; Entman, M.L.; Overbeek, P.A.; Michael, L.H.; Schneider, M.D. Telomerase Reverse Transcriptase Promotes Cardiac Muscle Cell Proliferation, Hypertrophy, and Survival. Proc. Natl. Acad. Sci. USA 2001, 98, 10308-10313. [CrossRef] [PubMed]

154. Murasawa, S.; Llevadot, J.; Silver, M.; Isner, J.M.; Losordo, D.W.; Asahara, T. Constitutive Human Telomerase Reverse Transcriptase Expression Enhances Regenerative Properties of Endothelial Progenitor Cells. Circulation 2002, 106, 1133-1139. [CrossRef]

155. Ait-Aissa, K.; Heisner, J.S.; Norwood Toro, L.E.; Bruemmer, D.; Doyon, G.; Harmann, L.; Geurts, A.; Camara, A.K.S.; Beyer, A.M. Telomerase Deficiency Predisposes to Heart Failure and Ischemia-Reperfusion Injury. Front. Cardiovasc. Med. $2019,6,31$. [CrossRef]

156. Haendeler, J.; Hoffmann, J.; Brandes, R.P.; Zeiher, A.M.; Dimmeler, S. Hydrogen Peroxide Triggers Nuclear Export of Telomerase Reverse Transcriptase via Src Kinase Family-Dependent Phosphorylation of Tyrosine 707. Mol. Cell. Biol. 2003, 23, 4598-4610. [CrossRef]

157. Büchner, N.; Zschauer, T.-C.; Lukosz, M.; Altschmied, J.; Haendeler, J. Downregulation of Mitochondrial Telomerase Reverse Transcriptase Induced by H2O2 Is Src Kinase Dependent. Exp. Gerontol. 2010, 45, 558-562. [CrossRef]

158. Hoffmann, J.; Richardson, G.; Haendeler, J.; Altschmied, J.; Andrés, V.; Spyridopoulos, I. Telomerase as a Therapeutic Target in Cardiovascular Disease. Arterioscler. Thromb. Vasc. Biol. 2021, 41, 1047-1061. [CrossRef]

159. Ale-Agha, N.; Jakobs, P.; Goy, C.; Zurek, M.; Rosen, J.; Dyballa-Rukes, N.; Metzger, S.; Greulich, J.; von Ameln, F.; Eckermann, O.; et al. Mitochondrial Telomerase Reverse Transcriptase Protects from Myocardial Ischemia/Reperfusion Injury by Improving Complex I Composition and Function. Circulation 2021, 144, 1876-1890. [CrossRef]

160. Harley, C.B.; Liu, W.; Flom, P.L.; Raffaele, J.M. A Natural Product Telomerase Activator as Part of a Health Maintenance Program: Metabolic and Cardiovascular Response. Rejuvenation Res. 2013, 16, 386-395. [CrossRef]

161. Maier, R.; Bawamia, B.; Bennaceur, K.; Dunn, S.; Marsay, L.; Amoah, R.; Kasim, A.; Filby, A.; Austin, D.; Hancock, H.; et al. Telomerase Activation to Reverse Immunosenescence in Elderly Patients With Acute Coronary Syndrome: Protocol for a Randomized Pilot Trial. JMIR Res. Protoc. 2020, 9, e19456. [CrossRef] 